\section{B A Institute of \\ YK Business Administration \\ 六下 \\ Karachi \\ Leadership and Ideas for Tomorrow}

Business Review

Volume 13 Issue 2 July-December 2018

$1-3-2019$

\title{
Empirical investigation of socially responsible investments in Pakistani firms using Carhart four factor model
}

\author{
Amna Ibrahim \\ International Islamic University, Islamabad, Pakistan \\ Tahira Awan \\ International Islamic University, Islamabad, Pakistan \\ Muhammad Yar Khan \\ COMSATS University, Islamabad
}

Follow this and additional works at: https://ir.iba.edu.pk/businessreview

\section{(c) (9)}

This work is licensed under a Creative Commons Attribution 4.0 International License.

\section{Recommended Citation}

Ibrahim, A., Awan, T., \& Khan, M. Y. (2019). Empirical investigation of socially responsible investments in Pakistani firms using Carhart four factor model. Business Review, 13(2), 51-80. Retrieved from https://doi.org/10.54784/1990-6587.1030 


\title{
Empirical investigation of socially responsible investments in Pakistani firms using Carhart Four Factor model
}

\author{
Amna Ibrahim - Tahira Awan . \\ Muhammad Yar Khan
}

\begin{abstract}
This study uses Carhart Four Factor Model to examine the impact of socially responsible investments on portfolio returns. Data has been collected from financial reports of socially responsible companies over the period 20102016. The results reveal that portfolio returns are explained significantly by market, size, book to market ratio, momentum and SRI whereas stock returns are not explained by momentum and SRI. This implies that investors can opt for socially responsible investments without compromising on returns.
\end{abstract}

Keywords Socially responsible investments - Carhart Four Factor Model · Portfolios · Ethical investors.

\section{Introduction}

Socially responsible investment (SRI) also known as sustainable, socially conscious, green or ethical investing is an investment strategy that provides good financial returns and simultaneously brings about positive societal change. The concept of socially responsible investment has gained momentum in recent years because of a greater focus on environmental, social and governance factors and assets are being managed based on the investment strategies followed by SRI investors (Scholtens et al 2014). Investors care about the monetary benefits but not at the expense of societal, social and environmental issues so positive and negative screening strategies are now used to make portfolios of stocks.

"Socially responsible investments (SRI) is the process of selecting or managing investments not with the aim of maximizing investor returns for given risk

Amna Ibrahim

International Islamic University, Islamabad-Pakistan

E-mail: amanaibrahim@yahoo.it

Tahira Awan

International Islamic University, Islamabad-Pakistan

Muhammad Yar Khan

COMSATS University, Islamabad-Pakistan 
per se, but of optimizing these parameters subject to social, environmental or ethical constraints" (Knowledge 2007). With socially responsible investing (SRI), social, environmental and ethical or governance issues are taken into account in addition to the financial criteria for decision making. It has been observed that over the past few decades people respond more positively to investments that provide not only good financial return but also good environmental and societal return (Bilbao-Terol et al 2012).

Socially responsible investing refers to investing in companies that have a good rating on environmental, social and governance issues (Hoti et al 2007). Companies are rated on the basis of corporate governance, community, diversity, employee relations, environment, human rights and products (Galema et al 2008; Kempf and Osthoff 2007). Companies scoring high on these dimensions are selected by SRI investors as a part of their portfolios.

There are the positive and negative screens in which the firms demonstrating socially acceptable behavior are screened in the SRI portfolio while the firms demonstrating socially unacceptable behavior are screened out from the portfolio. There are three basic differences in the practices adopted in standard portfolio management and SRI. Company policies about environment, workplace and international business practices are major issues which are considered to screen out or screen in the stock from the portfolio. Industries involved in gambling, tobacco and weapons productions are screened out from the SRI portfolio. The second major difference is the use of the governance mechanism by the SRI managers to influence corporate behavior through formal and informal discussions with the management. The third way in which the SRI portfolio differs from the standard portfolio is the investment of SRI funds for the welfare of the community like micro-enterprise or low-income housing. To protagonists, SRI is a powerful tool for achieving modest portfolio returns and positive social change in the society (Rivoli 2003).

Bollen (2007) argues that investors not only want to optimize the risk and reward but they also want the incorporation of some social and societal values while making investments. If investors are concerned about the social and personal values then it is expected that the SRI will grow further even at the cost of low SRI returns as compared to conventional investments. In accordance with the decision of the investors to make SRI investments, it is the management that decides whether to adopt CSR strategies such as sustainability of the environment, involvement of the community, diversity and human rights. The question here is does the adoption of CSR practices by the companies enhances the shareholders' value and whether investors would prefer the firms adopting CSR practices.

Portfolio theory regarding SRI says that limited diversification could harm the portfolio returns while the stakeholder theory (1988) suggests the addition of long-run profitable companies in the portfolio and socially responsible companies that care more about social and environmental factors work. When the investor screens out all the non-socially responsible companies from the portfolio they are left with the companies that have good relationship with the stakeholders and can earn good return in the long run. Companies caring about all stakeholders of the firm would have more satisfied employees resulting in 
higher returns than the companies not caring about the stakeholders (Edman 2011).

According to Markowitz (1952) investors have the option to choose from the well-organized portfolios based on their risk and return preferences. Socially responsible investors use different approaches for screening and selecting companies. Positive screening refers to the inclusion of socially and environmentally responsible companies in the portfolio while excluding unethical companies. This limits the diversification options available for the socially responsible investors and results in lower returns per unit of risk (Hamilton et al 1993).

Sharpe (1964), Lintner (1965) and Mossin (1969) introduced the capital asset pricing model. CAPM is used for the pricing of a single security or a portfolio and to assess the risk and returns of the assets. Fama and French three factor model (FF3F) is an extension of the CAPM model given by Fama and French (1992). The three factors of the Fama and French three factor model (FF3F) are company size, value and market factor as explained in CAPM. According to them, the size of the company (market capitalization) has a negative relation with the average returns of the firm and firms with higher book to market equity ratio produce higher average returns. Carhart (1997) extended the work of Fama and French and added the momentum factor to the existing model.

SRI has gained momentum in developed countries since 1980 but in the emerging countries socially responsible investing is still in its initial stages. This may be due to the lack of awareness among the investors. No research has yet been undertaken on socially responsible investing (SRI) in an emerging country like Pakistan. Investors prefer to invest in companies contributing to the good cause of the society and this research examines the extent to which socially responsible investing affects the returns of the portfolios along with market risk premium, size, book to market and momentum.

\section{Literature review}

Riedl and Smeets (2017) conducted a study to explore why investors prefer socially responsible investments. They used administrative data and responses of social surveys and found that investors social preferences are important in making SRI investments. Investors who are socially concerned would make SRI investments without caring about the returns.

Miralles-Quirós et al (2017) conducted a research on "improving diversification opportunities for socially responsible investors". This study revealed that SRI investors could reduce the risk of their portfolios by investing internationally. Charlo et al (2017) conducted a research to analyze the performance of socially responsible firms in Spain. The results of the cross-sectional study showed that responsible firms have huge size and higher systematic risk and this adds to the profits. Nakai et al (2016) worked to make a comparison of SRI funds and conventional funds in the Japanese market to check the impact of the global financial crisis in 2008. This was an event study which considered the bankruptcy of Lehman brothers. Fama and French three factors model and EGARCH model were used to evaluate the returns. The findings showed that

Business Review: (2018) 13(2):51-80 
SRI funds are less likely to suffer from bankruptcy then conventional funds.

Research by Tripathi and Bhandari (2015) showed that the returns associated with the portfolio of socially responsible stocks were higher than the portfolio of conventional stocks. The systematic risk for socially responsible stocks was higher but relative risk was lower. During the pre-crisis and post crisis the returns for socially responsible stocks were higher than the returns for conventional stocks.

Kempf and Osthoff (2007) examined the effect of socially responsible investing on portfolio performance by analyzing the stocks included in DS 400 and S\&P 500 by implementing the strategies for trading. Various screening policies were used for forming the portfolios of stocks and the performance of exclusionary and inclusionary stocks was measured using the Carhart (1997) four factor model. The results of this study showed that investors should buy stocks with high socially responsible ratings and sell stocks with low SRI ratings. The risk adjusted returns for the stocks with high SRI were higher than the returns for the stocks with low SRI.

Kremmer et al (2010) examined whether socially responsible investments are more sensitive to economic downturns as compared to conventional investments. It was found that socially responsible investments were less risky than conventional investments but during economic downturns, socially responsible investments were more exposed to risk than conventional investments. Galema et al (2008) related the six dimensions of SRI to the excess returns and book to market values. Data about socially responsible investments was collected from KLD research \& Analytics, Inc. KLD analyses firms on the basis of different criteria and positive and negative screens were used for the inclusion and exclusion of stocks from the SRI portfolios. SRI resulted in lower book to market ratio and the alpha values were not significant. The dimensions of SRI that rated high on environment, diversity and product were positively related to the stock returns.

The studies by Statman and Glushkov (2009) showed that investors are more attracted towards stocks of companies rated high on the characteristics of social responsibility while the stocks of companies involved in the production of alcohol, tobacco, gambling were rated low on social responsibility. Investors earned more return on stocks rated high on community, employee relations and environment but this advantage is offset by the disadvantage of excluding stocks of companies not included in the portfolio.

Hamilton et al (1993) found that there is no difference between the performance of socially responsible mutual funds and conventional mutual funds. Socially responsible investing has no effect on the returns of the stock and cost of capital. Barnett and Salomon (2006) examined the relationship between social responsibility and financial performance by using the modern portfolio theory. Stakeholder theory hypothesizes that the loss which the investors bear due to limited diversification in stocks of socially responsible firms is offset as the screening intensity increases because socially responsible portfolios are managed well. The results of this study showed that the financial performance of the firms changes with the type of screen. Community relations improve financial performance while environment and labor relations decreased financial perfor- 
mance.

The study by Leite and Cortez (2014) evaluated the different styles of investment and performance of socially responsible investment (SRI) funds located in Europe and made their comparison with the conventional mutual funds. Different investment styles were best in class screening strategies and positive/negative screening strategies. This study used the Carhart (1997) four factors model with the addition of the local factor. The results showed that there was no statistically significant difference between the performances of SRI funds and conventional funds located internationally. Conventional funds were performing better than the SRI funds when compared with their respective benchmarks. The results also showed that there is significant difference in the performance of funds when they use different investment styles. This difference in the results of SRI funds depends on the usage of screening strategies. SRI funds using best in-class screening strategies were significantly less exposed to small capitalized firms and momentum strategies and significantly highly exposed to local stocks.

Petrillo et al (2016) conducted study on socially responsible mutual funds in the Italian market. The objective of this study was to develop a methodology by which the investors could measure the attractiveness of socially responsible investments. The methodology used in this study was the ESG (environmental, social and governance) criteria based on the six dimensions of SRI which were corporate governance, community, diversity, employee relations, environment, human rights and products. These were further subdivided into 17 criteria. Different weights were assigned to the criteria by using analytic hierarchy process (AHP). This research is based on multi criteria models and the results showed that this methodology is easy and provides useful information for the investors demanding corporate social responsibility.

The study by the Mollet and Ziegler (2014) examined the relationship between socially responsible investing (SRI) and stock performance. This study was conducted in both the US and European markets and sustainability data was collected from all over the world. Carhart (1997) four factor model was used and the results show that SRI is associated with large size firms for both the US and European markets and supported the view that SRI stocks are correctly priced.

Hill et al (2007) compared the performance of SRI portfolios to that of nonSRI portfolios for the time period 1993 to 2003 and found the performance of SRI portfolios to be better than non-SRI portfolios. Research conducted by Statman (2000) to examine the performance of Domini social index and S\&P 500 for the time period 1990 to 1998 found that the risk adjusted returns of Domini social index are higher than the S\&P 500. The performance of SRI mutual funds was lower than the Domini social index and S\&P 500 but the performance of SRI mutual funds was higher than the conventional benchmarks. Statman et al (2006) found that the SRI indexes and S\&P are highly correlated and the performance of SRI indexes is higher than the S\&P 500.

Junkus and Berry (2015) reviewed the work on socially responsible investing and found no statistical difference between the performance of socially responsible funds/indexes and conventional funds/indexes but these results could vary 
depending on time period, model and benchmark. Renneboog et al (2008) argued that SRI investors value social characteristics over financial. Similarly Renneboog et al (2011) found that investors were more loyal towards SRI mutual funds than conventional ones because the cash flows of SRI were less sensitive to past returns.

Scholtens et al (2014) found that one fifth of the assets in the US and half of the assets in Europe were managed on the basis of seven socially responsible investment strategies. Unavailability of proper matrices to determine the size of socially responsible investment is a hindrance in the way for investors.

Several studies (Awan et al (2012); Bagh et al (2017); Iqbal et al (2012); Malik and Nadeem (2014)) have been also conducted in Pakistan which have investigated the relationship of corporate social responsibility with firm performance and other related decisions. Awan et al (2012) conducted research to analyze the level of corporate social responsibility in Pakistan. They employed a sample of 120 companies and data was gathered by distributing questionnaires. Using AMOS and SPSS, results of this study indicate that Pakistan has a moderate level of corporate social responsibility and main variables that scored high are social accountability and social investment.

Similarly, Bagh et al (2017) conducted study on corporate social responsibility and firm's financial performance in the financial sector of Pakistan using data for the 30 commercial banks for 10 years and the results suggest that the CSR has positive and significant impact on financial performance. However, no study have been conducted in Pakistan to test the relationship of SRI with stock returns.

From this literature it can be concluded that a lot of research has been conducted on socially responsible investments in developed and emerging countries. Sustainability indices available which rank the companies on the basis of social responsibility. Furthermore, some studies showed that the investor could earn higher returns by making investments in socially responsible companies while some studies showed that socially irresponsible companies earn higher returns. No study has yet been conducted on socially responsible investments in Pakistan so the objective of this study is to check whether the investor could earn higher return while preferring to make investments in socially responsible companies.

Following are the hypotheses that have been derived from previous literature.

CAPM is a single factor model which considers market risk to assess the excess returns of a portfolio or a security (Fama and French 1992). From this, following hypothesis has been derived. H1: Market risk premium has a significant impact on the returns of portfolios.

According to Fama and French (1992) size of the company (market capitalization) has a negative relation with the average returns of the firm and small capitalized firms tend to outperform large capitalize firms. Following hypothesis has been derived from this statement. H2: Size has a significant impact on the returns of portfolios.

Firms with higher book to market equity ratio earn higher average returns and outperform the companies with lower book to market ratio known as growth stocks (Fama and French 1992). From this statement we can derive the follow- 
ing hypothesis. H3: Book to market has significant impact on the returns of the portfolios.

Statman (2008) evidenced that small value companies with low momentum have higher subjective risks which in turn increases the objective risks of the stocks measurable by beta which would be recompense by higher expected returns so it can be hypothesized that H4: Momentum has a significant impact on the returns of portfolios.

The risk adjusted returns for the stocks with high SRI are higher than the returns for the stocks with low SRI (Kempf and Osthoff 2007). The following hypothesis can thus be derived. H5: SRI has a significant impact on the returns of the portfolios.

\section{Methodology}

The non-financial sector has been selected for this study and data has been collected for 80 firms for the time period 2010-2016. The firms were selected based on the CSR (corporate socially responsible) awards awarded by NFEH (National forum for environment and health). Forty companies were those that had received CSR awards whereas the remaining forty had not received CSR awards. The CSR awarded companies were called the SRI companies and others were the non-SRI companies. Portfolios have been constructed based on market risk premium, market capitalization, book to market, momentum and SRI with the returns of the firms.

Data for socially responsible investment has been taken from sustainability reports and financial reports of companies on the basis of the strengths and concerns of different dimensions of SRI. Data for the market capitalization, book-to-market, momentum and closing prices has been collected from the financial reports, business recorder, balance sheet analysis issued by the State Bank of Pakistan and from the website of Pakistan stock exchange (PSX). The rate of T-bills was obtained from the SBP website and average return of KSE100 index companies was obtained from PSX.

3.1 Construction of socially responsible investment index

Socially responsible investment (SRI) index has been developed on the basis of strengths and concerns along the following six dimensions.

1. Community (e.g., support for housing, generous giving)

2. Employee relations (e.g., cash profit sharing, strong union relations)

3. Corporate governance (e.g., lack of tax disputes, ownership)

4. Diversity (e.g., outstanding family benefits, promotion of women and minorities)

5. Products (e.g., provision of products for the economically disadvantage, product quality and safety)

6. Environment (e.g., recycling, pollution prevention)

Data for all the dimensions of SRI has been collected from financial and

Business Review: (2018) 13(2):51-80 
sustainability reports. Human rights have been skipped due to unavailability of this dimension in these reports. A score of 1 is assigned when a company demonstrates strength on an indicator (e.g., charitable giving) and 0 if it does not. Similarly, a score of 1 is assigned when a company's record raises concern on an indicator (e.g., investment controversies) and 0 otherwise. The score of a company on a given characteristic is the difference between the number of its strength indicators and the number of its concern indicators. In the end the score of the difference between the strength indicators and concern indicators have been added to give a final score to the company.

\subsection{Validity and reliability of the constructed variable}

Validity and reliability of researchers' self-constructed variables is always questionable. In this regard, Marston and Shrives (1991) argued that "the index scores awarded to companies can be considered to be reliable if the results can be replicated by another researcher. Since the scores are extracted from printed annual reports which remain constant over time there is no obstacle to repetition". The Cronbach Alpha test has been used to measure the reliability of the SRI index as it is evident from literature that it is one of most popular tests to measure the reliability of the self-constructed variable (Khan 2016; Sharma 2014). If the score of this test is between 70 to $80 \%$, the self-constructed variables is taken to be reliable (Pallant 2010).

Table 1: Reliability statistics

\begin{tabular}{cc}
\hline Cronbach's Alpha & N of Items \\
\hline 0.71 & 6.00 \\
\hline
\end{tabular}

The result of Cronbach Alpha test are shown in table 1. The alpha value for the six categories of SRI is 0.708 which suggests that there are less chances that measurement error may limit the power of empirical findings.

The other issue with construction of SRI is validity. According to Marston and Shrives (1991), "index scores can be considered to be valid if they mean what the researcher intended. Construct and content validity are the two main types of validity suggested in literature. Construct validity is when an included item in the constructed variable is relevant to what the researcher wants to test while content validity is about the inclusion of governance provisions in the constructed variable (Saunders et al 2009). In this research the SRI index is constructed with the consultation of senior researchers and by following the existing literature Renneboog et al $(2008,2011)$ to achieve construct validity and the inclusion of governance provisions assures content validity.

\section{Portfolio formation}

For the creation of Small minus big (SMB) factor, market capitalization has been used. Prices of stocks of different companies have been calculated and then these 
stocks have been ranked on the basis of market capitalization. Firstly, data for all the eighty companies has been arranged in descending order and the size sorted portfolios are constructed on the basis of market capitalization. The first set of portfolios above the median with higher market capitalization are said to be "big" portfolios while the others below the median with lower market capitalization are said to be "small". In the end SMB factor has been created by deducting the average return of the big portfolios from the average return of the small portfolios. Big and small portfolios are named as B and S respectively.

High minus low (HML) has been calculated on the basis of the book to market ratio. The two portfolios constructed based on market capitalization have been subdivided into portfolios. The Small has been divided into two portfolios on the basis of book to market ratio, one portfolio is said to be small high ( $\mathrm{SH}$ ) and other is said to be small low (SL). In the same way Big has been divided into two set of portfolios said to be Big high (BH) and Big low (BL). Forty small companies are further sorted on the basis of book to market ratio. The twenty small companies with higher book to market ratio are said to be $\mathrm{S} / \mathrm{H}$ and twenty with lower book to market ratio are said to be S/L. Similarly, big companies are also sorted on book to market ratio and twenty big companies with higher book to market ratio are said to be $\mathrm{B} / \mathrm{H}$ while twenty big companies with lower book to market ratio are said to be $\mathrm{B} / \mathrm{L}$. By taking the average returns of the portfolios HML factor has been created.

The $R_{m}-R_{f r}$ has been calculated by subtracting the average yield of twelvemonth treasury bills (T-bills) rate from the average return of the KSE 100 index companies as representation for the market. $R_{t}$ is the average return of each portfolio so $R_{t}-R_{f r}$ has been calculated by subtracting the weighted average yield of 12 months treasury bills (T-Bills) from the average return of all the portfolios.

For the calculation of the momentum factor average return for each company is calculated for every year and then the data for all the companies are further sorted on average return. Then the twenty small companies with higher book to market ratio are further subdivided into sub portfolios of ten companies each to create $\mathrm{S} / \mathrm{H} / \mathrm{W}$ and $\mathrm{S} / \mathrm{H} / \mathrm{L}$ and twenty small companies with lower book to market are further subdivided into two portfolios to make S/L/W and S/L/L. Twenty big companies with higher book to market ratio are subdivided into two portfolios of ten companies sorted on returns to make $\mathrm{B} / \mathrm{H} / \mathrm{W}$ and $\mathrm{B} / \mathrm{H} / \mathrm{L}$ and twenty big companies with lower book to market sorted on returns are subdivided into two portfolios to make $\mathrm{B} / \mathrm{L} / \mathrm{W}$ and $\mathrm{B} / \mathrm{L} / \mathrm{L}$ respectively.

SRI factor is calculated by further sorting the sample of ten companies which are sorted on returns to make the portfolios of 5 companies each. The $\mathrm{S} / \mathrm{H} / \mathrm{W}$ with higher SRI is said to be $\mathrm{S} / \mathrm{H} / \mathrm{W} / \mathrm{SRIH}$ and with lower SRI is $\mathrm{S} / \mathrm{H} / \mathrm{W} / \mathrm{SRIL}$ and the $\mathrm{S} / \mathrm{H} / \mathrm{L}$ portfolio with higher SRI is said to be $\mathrm{S} / \mathrm{H} / \mathrm{L} / \mathrm{SRIH}$ and with lower SRI is said to be S/H/LSRIL. S/L/W and S/L/L are further subdivided into portfolios on SRI and portfolio with higher SRI are said to be $\mathrm{S} / \mathrm{L} / \mathrm{W} / \mathrm{SRIH}$ and S/L/L/SRIH while portfolios with lower SRI are said to be $\mathrm{S} / \mathrm{L} / \mathrm{W} / \mathrm{SRIL}$ and $\mathrm{S} / \mathrm{L} / \mathrm{L} / \mathrm{SRILL} . \mathrm{B} / \mathrm{H} / \mathrm{W}$ and $\mathrm{B} / \mathrm{H} / \mathrm{L}$ with higher SRI make the $\mathrm{B} / \mathrm{H} / \mathrm{W} / \mathrm{SRIH}$ and $\mathrm{B} / \mathrm{H} / \mathrm{L} / \mathrm{SRIH}$ portfolio and with lower SRI are subdivided into $\mathrm{B} / \mathrm{H} / \mathrm{W} / \mathrm{SRIL}$ and $\mathrm{B} / \mathrm{H} / \mathrm{L} / \mathrm{SRIL} . \mathrm{B} / \mathrm{L} / \mathrm{W}$ and $\mathrm{B} / \mathrm{L} / \mathrm{L}$ with higher SRI 
make the $\mathrm{B} / \mathrm{L} / \mathrm{W} / \mathrm{SRIH}$ and $\mathrm{B} / \mathrm{L} / \mathrm{L} / \mathrm{SRIH}$ and with lower SRI are further subdivided into two portfolios which are said to be B/L/W/SRIL and B/L/L/SRIL respectively.

\section{Construction of variables}

The average return for portfolios such as $\mathrm{S}, \mathrm{B}, \mathrm{SH}, \mathrm{BH}$, SHW, SHL, BHW, BHL, SHWSRIH, SHWSRIL are calculated and then their averages are used to create variables. The variables created are market premium, size premium, value premium, MOM premium, SRI premium.

$$
\text { Marketriskpremium }=M R P=R_{m}-R_{f r}
$$

$$
\begin{aligned}
& S M B=1 / 14 *[(S H-B H)+(S L-B L)+(S H W-B H W)+(S H L-B H) \\
+ & (S H W S R I H-B H W S R I H)+(S H W S R I L-B H W S R I L)+(S H L S R I H-B H L S R I H) \\
+ & (S H L S R I L-B H L S R I L)+(S L W-B L W)+(S L L-B L L)+(S L W S R I H-B L W S R I H) \\
+ & (S L W S R I L-B L W S R I L)+(S L L S R I H-S H L S R I H)+(S L L S R I L-S H L S R I L)]
\end{aligned}
$$

$$
\begin{aligned}
& H M L=1 / 14 *[(S H-S L)+(S H W-S L W)+(S H L-S L L)+(S H W S R I H-S L W S R I H) \\
+ & (S H W S R I L-S L W S R I L)+(S H L S R I H-S L L S R I H)+(S H L S R I L-S L L S R I L) \\
+ & (B H-B L)+(B H W-B L W)+(B H L-B L L)+(B H W S R I H-B L W S R I H) \\
+ & (B H W S R I L-B L W S R I L)+(B H L S R I H-B L L S R I H)+(B H L S R I L-B L L S R I L)]
\end{aligned}
$$

$$
\begin{aligned}
& W M L=1 / 12 *[(S H W-S H L)+(S L W-S L L)+(S H W S R I H-S H L S R I H) \\
&+(S L W S R I H-S L L S R I H)+(S H W S R I L-S H L S R I L)+(S L W S R I L-S L L S R I L) \\
&+(B H W-B H L)+(B L W-B L L)+(B H W S R I H-B H L S R I H)+(B L W S R I H-B L L S R I H) \\
&+(B H W S R I L-B H L S R I L)+(B L W S R I L-B L L S R I L)] \quad(4) \\
& \quad S R I=1 / 8 *[(S H W S R I H-S H W S R I L)+(S H L S R I H-S H L S R I L) \\
&+(S L W S R I H-S L W S R I L)+(S L L S R I H-S L L S R I L)+(B H W S R I H-B H W S R I L) \\
&+(B H L S R I H-B H L S R I L)+(B L W S R I H-B L W S R I L)+(B L L S R I H-B L L S R I L)]
\end{aligned}
$$

60 


\section{Model specification and regression estimation method}

The algebraic relationship between the dependent and independent variables is:

$R i_{t}-R f_{t}=\alpha+\beta 1_{i}\left(R_{m}-R_{f t}\right)+\beta 2_{i} S M B_{t}+\beta 3_{i} H M L_{t}+\beta 4_{i} M O M_{t}+\beta 4_{i} S R I_{t}+\epsilon i_{t}$

where,

$R_{t}=$ returns of the portfolios for period $\mathrm{t}$

$R_{f r}=$ Risk free Rate of return (weighted average yield of 12 Months T- Bills)

$\left(R_{m}-R_{f r}\right)=$ Market premium

$S M B=$ Size premium

$H M L=$ Value premium

$S R I=$ socially responsible investment

$\alpha=$ Constant

$\beta 1=$ Coefficient of market premium

$\beta 1=$ Coefficient of size premium

$\beta 1=$ Coefficient of value premium

$\beta 1=$ Coefficient of socially responsible investment

$\epsilon=$ error term

\section{Results}

The descriptive statistics in table 2 for portfolios constructed on the basis of size, book to market, WML and SRI show that the BHW (Big high winners) has the highest level of returns with the mean value of .009813 or $.98 \%$ with the standard deviation of 0.0300 or $3.00 \%$. After that the highest returns are present in case of BL (big low) portfolio .0095 or .95\% and BHWSRIL (big high winners to low socially responsible investments) with the mean value of .00939 Or $.939 \%$ with the standard deviation of .0173 or $1.73 \%$ and .0323 or $3.23 \%$ respectively.

The lowest level of returns are present in case of SHLSRIH (small high to low book to market and socially responsible investment high) with the mean value of .000481 and BHLSRIL (big high low book to market and socially responsible investment low) .000915 with the standard deviation of .032 or $3.2 \%$ and .028 or $2.8 \%$ respectively. When socially responsible investment is considered BHWSRIH (big high winners and socially responsible investment high) earns return of 0.010236 or $1.0 \%$ while BLWSRIH (big low winners to high socially responsible investments) earn a return of 0.018217 or $1.82 \%$ and BLWSRIL (big low winners to low socially responsible investments) earn a return of .01459 or $1.45 \%$ with the standard deviation of 0.032261 or $3.2 \%$ and 0.025143 or $2.5 \%$ respectively with the minimum and maximum value of $-0.04264,-0.03735$ and 0.110906 and 0.087954 respectively. The mean and median values of these portfolios are different from each other.

In order to use OLS regression, it is suggested that data should be normally distributed. For this purpose, skewness and kurtosis tests have been used in this study. According to Gujarati (2009), kurtosis and skewness acceptance values 
are zero and three for normal data. The values for these tests are reported in table 2 and show that skewness values are asymmetrically distributed with some negative and positive skewed data from mean while the kurtosis values show scattered data in some cases.

The descriptive statistics in table 3 for the five factors show that the mar-

Table 2: Descriptive statistics of portfolios

\begin{tabular}{|c|c|c|c|c|c|c|c|}
\hline Variables & Mean & Median & $\mathrm{SD}$ & Skewness & Kurtosis & Minimum & Maximum \\
\hline $\mathrm{P}$ & 0.006 & 0.009 & 0.022 & -0.271 & 0.010 & -0.044 & 0.063 \\
\hline $\mathrm{S}$ & 0.005 & 0.008 & 0.025 & -0.257 & -0.209 & -0.052 & 0.063 \\
\hline B & 0.007 & 0.010 & 0.020 & -0.032 & 0.350 & -0.045 & 0.064 \\
\hline $\mathrm{SH}$ & 0.002 & 0.002 & 0.027 & -0.167 & -0.129 & -0.063 & 0.057 \\
\hline $\mathrm{SL}$ & 0.008 & 0.009 & 0.026 & -0.082 & 0.437 & -0.052 & 0.090 \\
\hline SHW & 0.005 & 0.004 & 0.030 & 0.192 & 0.437 & -0.067 & 0.085 \\
\hline SHL & -0.002 & -0.001 & 0.029 & -0.257 & 0.155 & -0.081 & 0.075 \\
\hline SHWSRIH & 0.007 & 0.007 & 0.029 & 0.220 & 0.043 & -0.058 & 0.083 \\
\hline SHWSRIL & 0.003 & 0.003 & 0.035 & 0.505 & 1.166 & -0.083 & 0.117 \\
\hline SHLSRILH & 0.000 & 0.000 & 0.033 & 0.516 & 1.973 & -0.089 & 0.129 \\
\hline SHLSRIL & -0.004 & -0.001 & 0.034 & -0.139 & -0.300 & -0.098 & 0.064 \\
\hline SLW & 0.011 & 0.012 & 0.029 & -0.086 & -0.109 & -0.056 & 0.080 \\
\hline SLL & 0.006 & 0.004 & 0.030 & 0.398 & 0.525 & -0.062 & 0.101 \\
\hline SLWSRILH & 0.009 & 0.009 & 0.028 & 0.090 & -0.074 & -0.054 & 0.078 \\
\hline SLWSRIL & 0.013 & 0.011 & 0.041 & 0.183 & 0.739 & -0.098 & 0.128 \\
\hline SLLSRIH & 0.006 & 0.005 & 0.035 & 0.286 & 0.810 & -0.081 & 0.112 \\
\hline SLLSRIL & 0.005 & 0.003 & 0.040 & 0.561 & 1.376 & -0.083 & 0.134 \\
\hline B & 0.007 & 0.010 & 0.020 & -0.032 & 0.350 & -0.045 & 0.064 \\
\hline $\mathrm{BH}$ & 0.006 & 0.007 & 0.025 & 0.034 & 0.664 & -0.062 & 0.080 \\
\hline $\mathrm{BL}$ & 0.010 & 0.009 & 0.017 & -0.002 & -0.137 & -0.032 & 0.054 \\
\hline BHW & 0.010 & 0.014 & 0.030 & -0.333 & 0.237 & -0.076 & 0.087 \\
\hline BHL & 0.001 & -0.001 & 0.026 & 0.449 & 1.504 & -0.067 & 0.083 \\
\hline BHWSRIH & 0.010 & 0.011 & 0.032 & -0.359 & 0.710 & -0.083 & 0.103 \\
\hline BHWSRIL & 0.009 & 0.012 & 0.032 & -0.068 & -0.206 & -0.068 & 0.089 \\
\hline BHLSRIH & 0.001 & -0.001 & 0.028 & 0.568 & 1.304 & -0.063 & 0.099 \\
\hline BHLSRIL & 0.001 & 0.002 & 0.029 & -0.063 & 1.519 & -0.082 & 0.091 \\
\hline BLW & 0.016 & 0.017 & 0.023 & 0.151 & -0.842 & -0.029 & 0.067 \\
\hline BLL & 0.003 & 0.005 & 0.018 & -0.590 & 1.156 & -0.054 & 0.042 \\
\hline BLWSRIH & 0.018 & 0.015 & 0.032 & 0.357 & -0.294 & -0.043 & 0.111 \\
\hline BLWSRIL & 0.015 & 0.009 & 0.025 & 0.537 & 0.289 & -0.037 & 0.088 \\
\hline BLLSRIH & 0.002 & 0.001 & 0.026 & 0.114 & 0.865 & -0.070 & 0.078 \\
\hline BLLSRIL & 0.003 & 0.003 & 0.020 & -0.417 & 0.238 & -0.051 & 0.053 \\
\hline
\end{tabular}

ket premium, WML premium and SRI premium are positive while the size and value premium are negative but the volatility of market premium and WML premium is higher as compared to the size, value and SRI premium. The WML premium shows that the WML stocks have the highest mean value then size, value and SRI stocks. When compared to size, value, WML and SRI stocks, the descriptive statistics show that market premium has more volatility as compared to other premiums. The WML has the highest premium .00867 0r .867\% with the standard deviation of .0138 or $1.38 \%$. The market premium has the highest standard deviation .0423 or $4.23 \%$ with the mean value of .0528 or $5.28 \%$.

The mean and median are close to each other in case of size, value, WML and SRI stocks except in market premium which are different from each other. 
Empirical investigation of socially responsible investments ...

Table 3: Descriptive statistics of five factors

\begin{tabular}{lccccc}
\hline Variables & Rm-Rfr & SMB & HML & WML & SRI \\
\hline Mean & 0.053 & -0.003 & -0.005 & 0.009 & 0.001 \\
Median & 0.014 & -0.002 & -0.005 & 0.008 & 0.003 \\
Std Dev & 0.042 & 0.014 & 0.014 & 0.014 & 0.013 \\
Kurtosis & 1.512 & -0.577 & 0.246 & 1.613 & -0.595 \\
Skewness & -0.571 & 0.256 & 0.167 & -0.232 & 0.096 \\
Minimum & -0.122 & -0.031 & -0.038 & -0.038 & -0.023 \\
Maximum & 0.132 & 0.028 & 0.034 & 0.051 & 0.036 \\
\hline
\end{tabular}

The results of skewness show that the market premium and WML are negatively skewed means that the distribution is negatively skewed and asymmetrical with the long tail to the left of the mean while the size, value and SRI premiums are positively skewed with asymmetrical distribution with the long tail to the right side of the mean.

The results of kurtosis show that all the premiums are positive, data is leptokurtic with peaked curve while the size premium is negative with platykurtic curve which shows dispersion in the data. The results presented in the Appendix for capital asset pricing model show that there exists significant relationship with the returns of the portfolios when market premium is considered and these results are in line with the capital asset pricing model Sharpe (1964). All the portfolios show positive returns and the relationship is significant when the market factor is considered which means the market significantly explains the returns and this factor should not be overlooked while making the investment decisions.

The results of Fama and French three factor model show that there exists positive and significant relationship in case of portfolios $\mathrm{S}$ (small), $\mathrm{SH}$ (small high), SL (small low), SHW (small high winners), SHL (small high losers), SHWSRIH (small high winners to high socially responsible investments), SHLSRIH (small high losers to high socially responsible investments), SHLSRIL (small high losers to low socially responsible investments), SLW (small low winners), SLL (small low losers), SLWSRIH (small low winners to high socially responsible investments), SLWSRIL (small low winners to low socially responsible investments), SLLSRIH (small low losers to high socially responsible investments), SLLSRIL (small low losers to low socially responsible investments) except the portfolio SHWSRIL (small high winners to low socially responsible investments) which shows an insignificant relationship. These results are in line with Fama and French (1992) that small capitalized firms tend to outperform the large capitalized firms.

The results in case of value premium shows that there exists significant relationship in case of S (small), B (big), SH (small high), SHW (small high winners), SHL (small high losers), SHWSRIH (small high winners to high socially responsible investments),SHWSRIL (small high winners to low socially responsible investments), SHLSRIH (small high losers to high socially responsible investments), SHLSRIL (small high losers to low socially responsible investments), BH (big high), BHW (big high winners), BHL (big high losers), BHWSRIH (big high winners to high socially responsible investments), BHWS-

Business Review: (2018) 13(2):51-80 
RIL (big high winners to low socially responsible investments), BHLSRIH (big high losers to high socially responsible investments), BHLSRIL (big high losers to low socially responsible investments). All the $\mathrm{p}$ values are significant at $95 \%$ confidence interval.

Our results are consistent with the findings of Stattman (1980) that big companies earn low returns as compared to small companies and low book to market stocks under perform as compared to the higher book to market stocks. All the portfolios with higher book to market show statistically significant results and these results do not show significant results when book to market is low and these results are in line with Hassan and Javed (2011) that low book to market stocks are not explained by HML.

In Carhart four factor model, size premium is positive and significant in case of S (small), SH (small high), SL (small low), SHW (small high winners), SHWSRIH (small high winners to high socially responsible investment), SHWSRIL (small high winners to low socially responsible investment), SHLSRIH (small high losers to low socially responsible investment). Returns are positive and relationship is significant in all other portfolios except B (big), BH (big high), BL (big low), BHW (big high winners), BHL (big high losers), BHWSRIH (big high winners to high socially responsible investment), BHWSRIL (big high winners to low socially responsible investment), BHLSRIL (big high losers to low socially responsible investments), BLW (big low winners), BLL (big low losers), BLWSRIH (big low winners to high socially responsible investments), BLWSRIL (big low winners to low socially responsible investment), BLLSRIH (Big low losers to high socially responsible investments), BLLSRIL (big low losers to low socially responsible investments).

Value premium is positive and significant except the SL (small losers), SLW (small low winners), SLL (small low losers), SLWSRIL (small low winners to low socially responsible investments), SLLSRIH (small low losers to high socially responsible investments), SLLSRIL (small low losers to low socially responsible investments), BL (big low), BLW (big low winners), BLL (big low losers), BLWSRIH (big low winners to high socially responsible investments), BLWSRIL (big low winners to low socially responsible investments), BLLSRIH (big low losers to high socially responsible investments), BLLSRIL (big low losers to low socially responsible investments).

The results of WML premium are positive and significant in case of SHW (small high winners), SHWSRIH (small high winners to high socially responsible investments), SHWSRIL (small high winners to low socially responsible investments), SLW (small low winners), SLWSRIH (small low winners to high socially responsible investments), SLWSRIL (small low winners to low socially responsible investments), BHW (big high winners), BHWSRIH (big high winners to high socially responsible investments), BHWSRIL (big low winners to low socially responsible investments), BLW(big low winners), BLWSRIH (big low winners to high socially responsible investments), BLWSRIL (big low winners to low socially responsible investments). All the $\mathrm{p}$ values show significance at $95 \%$ confidence interval, when $\mathrm{p}$ is less than or equal to .05.

Fama and French (1992) discussed the presence of higher objective risk in the stock of small value companies as compared to the stocks of companies with 
higher growth. Statman (2008) evidenced that small value companies with low momentum have higher subjective risks which in turn increases the objective risks of the stocks measurable by beta which would be recompense by higher expected returns. The study by Jegadeesh and Titman (1993) reveals that higher returns are earned by the winners' firms as compared to loser firms and this study confirms our results that the portfolios with winner stocks outperform the portfolios with loser stocks.

The results of Additional factor (SRI) show that there exists a significant and positive relationship in case of the size premium except in case of B (big), BH (big high), BL (big low), BHW (big high winners), BHL (big high losers), BHWSRIH (big high winners to high socially responsible investments), BHWSRIL (big high winners to low socially responsible investments), BHLSRIH (big high losers to high socially responsible investments), BHLSRIL (big high losers to low socially responsible investments), BLW (big low winners), BLL (big low losers), BLWSRIH (big low winners to high socially responsible investments), BLWSRIL (big low winners to low socially responsible investments), BLLSRIH (big low losers to high socially responsible investments), BLLSRIL (big low losers to low socially responsible investments).

For value premium there exists a significant and positive relationship except in case of SL (small low), SLW (small low winners), SLL (small low losers), SLWSRIH (small low winners to high socially responsible investments), SLWSRIL (small low winners to low socially responsible investments), SLLSRIH (small low losers to high socially responsible investments), BL (big low), BLW (big low winners), BLL (big low losers), BLWSRIH (big low winners to high socially responsible investments), BLWSRIL (big low winners to low socially responsible investments), BLLSRIH (big low losers to high socially responsible investments), BLLSRIL (big low losers to low socially responsible investments). All the portfolios with low book to market show insignificant results while the companies with high book to market show significant results. This result is consistent with Fama and French (1992) that stocks of companies with high book to market outperform the companies with low book to market.

WML premium shows a positive and significant relationship in case of SHW (small high winners), SHWSRIH (small high winners to high socially responsible investments), SHWSRIL (small high winners to low socially responsible investments), SLWSRIH (small low winners to high socially responsible investments), SLWSRIL (small low winners to low socially responsible investments), SLW (small low winners), BHW (big high winners), BHWSRIH (big high winners to high socially responsible investments), BHWSRIL (big high winners to low socially responsible investments), BHLSRIL (big high losers to low socially responsible investments), BLW (big low winners), BLWSRIH (big low winners to high socially responsible investments), BLWSRIL (big low winners to low socially responsible investments), BLLSRIH (big low losers to high socially responsible investments) and WML portfolio shows negative but significant relationship in case of SHLSRIH (small high losers to high socially responsible investments), SLL (small low losers), SLLSRIL (small low losers to low socially responsible investments). All the winners' companies show the significant results. These results are also consistent with Jegadeesh and Titman (1993) study that winners' 
stocks outperform the losers' stocks. All the p values show significance at 95\% confidence interval, when $\mathrm{p}$ is less than .05 .

SRI portfolios show positive returns and significant relationship in SHWSRIH (small high winners to high socially responsible investments), SLWSRIH (small low winners to high socially responsible investments), SLLSRIH (small low losers to high socially responsible investments), and BLLSRIH (big low losers to high socially responsible investments). Tripathi and Bhandari (2015) shows that the returns associated with the portfolio of socially responsible stocks is higher than the portfolio of conventional stocks. The study by Kempf and Osthoff (2007) shows that investors should buy stocks with high socially responsible ratings and sell stocks with low SRI ratings. The risk adjusted returns for the stocks with high SRI are higher than the returns for the stocks with low SRI.

Regression results of portfolios with high social responsibility show significant results which means that the companies involved in high social responsibility earn higher returns. Galema et al (2008) relates the six dimensions of SRI to the excess returns and book to market values. SRI results in the lower book to market ratio and the alpha values were not significant. The dimensions of SRI that rated high on environment, diversity and product are positively related to the returns.

\subsection{Comparative statement of adjusted $R^{2}$}

Table 4 shows the comparative statement of adjusted R square for FF3F, Carhart Four Factor Model and for the Additional factor model. The single factor model shows that the $28 \%$ variation in returns is explained by market factor but when the FF3F model is applied it lead to the increase in the values of Adj. R square and $73 \%$ variation in returns is explained by market, size and value factor while Carhart four factor model lead to the increase in the value of $\mathrm{R}$ square for different portfolios and ranges from $13 \%$ to $73 \%$ and additional factor model-SRI also led to the increase in the value of adjusted $\mathrm{R}$ square for different portfolios and value ranges from $17 \%$ to $73 \%$. These findings are in line with the previous literature (Hassan and Javed 2011; Kempf and Osthoff 2007; Pokorna ????).

The overall value for adjusted $\mathrm{R}$ square does not increase in case of WML and SRI which shows that momentum and socially responsible investment does not significantly explain the returns of the stocks which again means that these findings are consistent with (Hassan and Javed 2011; Kempf and Osthoff 2007).

\section{Conclusion}

Several researches have been conducted on socially responsible investments in developed countries. Sustainability index or socially responsible index has also been created for the ease of the investors but in developing countries like Pakistan no research has been published regarding the impact of corporate social responsibility stock returns. This study is an effort to check the impact of social responsibility on stock returns in Pakistan. 
Empirical investigation of socially responsible investments ...

Table 4: Comparative statement of adjusted $R^{2}$

\begin{tabular}{lcccc}
\hline $\begin{array}{l}\text { Dependent } \\
\text { variable }\end{array}$ & CAPM & 3FM-FF & $\begin{array}{l}\text { 4FM- } \\
\text { CARHART }\end{array}$ & $\begin{array}{l}\text { Additional } \\
\text { factor } \\
\text {-SRI }\end{array}$ \\
\hline P & & & \multicolumn{2}{l}{ model } \\
S & 0.22 & 0.48 & 0.48 & 0.48 \\
B & 0.14 & 0.62 & 0.62 & 0.62 \\
SH & 0.28 & 0.38 & 0.38 & 0.38 \\
SL & 0.12 & 0.73 & 0.73 & 0.73 \\
SHW & 0.14 & 0.49 & 0.49 & 0.49 \\
SHL & 0.08 & 0.64 & 0.7 & 0.69 \\
SHWSRIH & 0.13 & 0.61 & 0.62 & 0.63 \\
SHWSRIL & 0.07 & 0.55 & 0.57 & 0.6 \\
SHLSRIH & 0.11 & 0.54 & 0.6 & 0.62 \\
SHLSRIL & 0.08 & 0.49 & 0.52 & 0.53 \\
SLW & 0.11 & 0.41 & 0.42 & 0.49 \\
SLL & 0.1 & 0.34 & 0.54 & 0.54 \\
SLWSRIH & 0.08 & 0.23 & 0.31 & 0.38 \\
SLWSRIL & 0.07 & 0.35 & 0.44 & 0.36 \\
SLLSRIH & 0.09 & 0.22 & 0.25 & 0.51 \\
SLLSRIL & 0.04 & 0.21 & 0.24 & 0.35 \\
BH & 0.17 & 0.47 & 0.47 & 0.46 \\
BL & 0.36 & 0.35 & 0.35 & 0.34 \\
BHW & 0.15 & 0.36 & 0.44 & 0.44 \\
BHL & 0.15 & 0.42 & 0.46 & 0.47 \\
BHWSRIH & 0.17 & 0.36 & 0.41 & 0.4 \\
BHWSRIL & 0.08 & 0.28 & 0.37 & 0.37 \\
BHLSRIH & 0 & 0.36 & 0.37 & 0.37 \\
BHLSRIL & 0.07 & 0.34 & 0.39 & 0.45 \\
BLW & 0.26 & 0.26 & 0.37 & 0.38 \\
BLL & 0.25 & 0.24 & 0.28 & 0.28 \\
BLWSRIH & 0.23 & 0.22 & 0.31 & 0.31 \\
BLWSRIL & 0.11 & 0.12 & 0.16 & 0.32 \\
BLLSRIH & 0.08 & 0.07 & 0.13 & 0.17 \\
BLLSRIL & 0.27 & 0.25 & 0.25 & 0.29 \\
\hline & & & &
\end{tabular}

The results in case of size premium are positively and significantly related to small portfolios except the big portfolios which shows that size premium factor exists in Pakistan. The results of value premium show that the portfolios with high book to market outperform the portfolios with low book to market and results show significance when the book to market is high.

The results in case of momentum premium show significance in case of winner and big companies having high momentum. These results are also in line with the research done by Statman (2008). SRI premium shows significant results when the social responsibility of the companies is high. Further it can be induced from the results that socially responsible firms have a competitive advantage that has an impact on the returns of the firm.

These results are in line with the research done by Tripathi and Bhandari (2015) that the stocks with social responsibility earn higher returns than the conventional stocks. In Pakistan, investors should consider the factor of size, book to market, momentum and social responsibility when making investment decisions. 
8.1 Policy recommendations and future horizon

This study has several policy implications for socially responsible investors in Pakistan. The need to create the awareness among investors about social responsibility prevails. Investors who are making profitable investments otherwise could gain much higher profit margins by investing their money in socially responsible companies. The results of this study are useful for companies, as the returns of the investors associated with socially responsible firms are comparatively higher than the firms which are not socially responsible.

This study presents outcomes for the future researchers as well. A perceptual study regarding an understanding of the mindset of investors related to corporate social responsibility needs to be conducted. Conducting a qualitative survey regarding the perceptions of investors can be a valuable contribution to the discipline. Further more, only non financial firms were taken into account in this study, a similar study on non-financial firms would be an important contribution.

\section{References}

Awan AW, Kamal Y, Rafique M, Khan S (2012) Corporate social responsibility in pakistan economy

Bagh T, Khan MA, Azad T, Saddique S, Khan MA (2017) The corporate social responsibility and firms financial performance: Evidence from financial sector of pakistan. International Journal of Economics and Financial Issues 7(2):301-308

Barnett ML, Salomon RM (2006) Beyond dichotomy: The curvilinear relationship between social responsibility and financial performance. Strategic Management Journal 27(11):11011122

Bilbao-Terol A, Arenas-Parra M, Cañal-Fernández V (2012) Selection of socially responsible portfolios using goal programming and fuzzy technology. Information Sciences 189:110125

Bollen NP (2007) Mutual fund attributes and investor behavior. Journal of Financial and Quantitative Analysis 42(3):683-708

Carhart MM (1997) On persistence in mutual fund performance. The Journal of finance 52(1):57-82

Charlo MJ, Moya I, Muñoz AM (2017) Sustainable development in spanish listed companies: A strategic approach. Corporate Social Responsibility and Environmental Management $24(3): 222-234$

Edman BR (2011) Leases: Off-balance sheet financing and the strive for transparency today

Fama EF, French KR (1992) The cross-section of expected stock returns. the Journal of Finance 47(2):427-465

Galema R, Plantinga A, Scholtens B (2008) The stocks at stake: Return and risk in socially responsible investment. Journal of Banking \& Finance 32(12):2646-2654

Gujarati DN (2009) Basic econometrics. Tata McGraw-Hill Education

Hamilton S, Jo H, Statman M (1993) Doing well while doing good? the investment performance of socially responsible mutual funds. Financial Analysts Journal 49(6):62-66

Hassan A, Javed MT (2011) Size and value premium in pakistani equity market. African Journal of Business Management 5(16):6747-6755

Hill RP, Ainscough T, Shank T, Manullang D (2007) Corporate social responsibility and socially responsible investing: A global perspective. Journal of Business Ethics 70(2):165174

Hoti S, McAleer M, Pauwels LL (2007) Measuring risk in environmental finance. Journal of Economic Surveys 21(5):970-998 
Iqbal N, Ahmad N, Basheer NA, Nadeem M (2012) Impact of corporate social responsibility on financial performance of corporations: Evidence from pakistan. International journal of learning and development 2(6):107-118

Jegadeesh N, Titman S (1993) Returns to buying winners and selling losers: Implications for stock market efficiency. The Journal of finance 48(1):65-91

Junkus J, Berry TD (2015) Socially responsible investing: a review of the critical issues. Managerial Finance 41(11):1176-1201

Kempf A, Osthoff P (2007) The effect of socially responsible investing on portfolio performance. European Financial Management 13(5):908-922

Khan MY (2016) Corporate governance and cost of capital: evidence from pakistani listed firms. PhD thesis, University of Glasgow

Knowledge OB (2007) Recent trends and regulatory implications in socially responsible investment for pension funds. Report Prepared for the OECD Roundtable on Corporate Responsibility

Kremmer M, Brimble M, Freudenberg B, Cameron C (2010) Numeracy of first year commerce students: Preliminary analysis of an intervention. International Journal of Learning 17(1):1-13

Leite P, Cortez MC (2014) Style and performance of international socially responsible funds in europe. Research in International Business and Finance 30:248-267

Lintner J (1965) Security prices, risk, and maximal gains from diversification. The journal of finance 20(4):587-615

Malik MS, Nadeem M (2014) Impact of corporate social responsibility on the financial performance of banks in pakistan. International Letters of Social and Humanistic Sciences 10(1):9-19

Markowitz H (1952) Portfolio selection. The journal of finance 7(1):77-91

Marston CL, Shrives PJ (1991) The use of disclosure indices in accounting research: a review article. The British Accounting Review 23(3):195-210

Miralles-Quirós MdM, Miralles-Quirós JL, Oliveira C (2017) The role of liquidity in asset pricing: the special case of the portuguese stock market. Journal of Economics, Finance and Administrative Science 22(43):191-206

Mollet JC, Ziegler A (2014) Socially responsible investing and stock performance: New empirical evidence for the us and european stock markets. Review of Financial Economics $23(4): 208-216$

Mossin J (1969) Security pricing and investment criteria in competitive markets. The American Economic Review 59(5):749-756

Nakai M, Yamaguchi K, Takeuchi K (2016) Can sri funds better resist global financial crisis? evidence from japan. International Review of Financial Analysis 48:12-20

Pallant J (2010) Spss survival manual: A step by step guide to data analysis using spss . maidenhead

Petrillo A, De Felice F, García-Melón M, Pérez-Gladish B (2016) Investing in socially responsible mutual funds: Proposal of non-financial ranking in italian market. Research in International Business and Finance 37:541-555

Pokorna M (????) Socially responsible investing and portfolio performance

Renneboog L, Ter Horst J, Zhang C (2008) Socially responsible investments: Institutional aspects, performance, and investor behavior. Journal of Banking \& Finance 32(9):17231742

Renneboog L, Ter Horst J, Zhang C (2011) Is ethical money financially smart? nonfinancial attributes and money flows of socially responsible investment funds. Journal of Financial Intermediation 20(4):562-588

Riedl A, Smeets P (2017) Why do investors hold socially responsible mutual funds? The Journal of Finance 72(6):2505-2550

Rivoli P (2003) Making a difference or making a statement? finance research and socially responsible investment. Business Ethics Quarterly 13(3):271-287

Saunders M, Lewis P, Thornhill A (2009) Research methods for business students. Pearson education

Scholtens S, Smidt N, Swertz MA, Bakker SJ, Dotinga A, Vonk JM, van Dijk F, van Zon SK, Wijmenga C, Wolffenbuttel BH, et al (2014) Cohort profile: Lifelines, a three-generation cohort study and biobank. International journal of epidemiology 44(4):1172-1180

Business Review: (2018) 13(2):51-80 
Sharma N (2014) Extent of corporate governance disclosure by banks and finance companies listed on nepal stock exchange. Advances in accounting 30(2):425-439

Sharpe WF (1964) Capital asset prices: A theory of market equilibrium under conditions of risk. The journal of finance 19(3):425-442

Statman M (2000) Socially responsible mutual funds (corrected). Financial Analysts Journal $56(3): 30-39$

Statman M (2008) The expressive nature of socially responsible investors

Statman M, Glushkov D (2009) The wages of social responsibility. Financial Analysts Journal $65(4): 33-46$

Statman M, Thorley S, Vorkink K (2006) Investor overconfidence and trading volume. The Review of Financial Studies 19(4):1531-1565

Stattman D (1980) Book values and stock returns. The Chicago MBA: A journal of selected papers $4(1): 25-45$

Tripathi V, Bhandari V (2015) Socially responsible stocks: a boon for investors in india. Journal of Advances in Management Research 12(2):209-225 


\section{Appendix}

\begin{tabular}{ll}
\multicolumn{1}{c}{ Table A1: List of acronyms } \\
\hline B & Big \\
BHWSRIH & Big High Winners to High Socially Responsible Investments \\
BHWSRIL & Big High Winners to Low Socially Responsible Investments \\
BTM & Book to Market Equity \\
CSR & Corporate Social Responsibility \\
CAPM & Capital Asset Pricing Model \\
FF3F & Fama And Three Factors Model \\
HML & High Minus Low \\
MOM & Momentum \\
ME & Market Value of Equity \\
MKT & Market \\
NFEH & National Forum for Environment and Health \\
P & Portfolio \\
RM & Market Returns \\
RM-RFR & Market Risk Premium \\
RFR & Risk Free Rate \\
SMB & Small minus Big \\
SRI & Socially Responsible Investments \\
S & Small \\
SH & Small High \\
SL & Small Low \\
SHW & Small High Winners \\
SHL & Small High Losers \\
WML & Winners Minus Losers \\
SECP & Securities and Exchange Commission of Pakistan \\
PSX & Pakistan Stock Exchange \\
\hline
\end{tabular}

Business Review: (2018) 13(2):51-80 
A. Ibrahim et al

Table A2: Additional factor model (SRI)

\begin{tabular}{lrrrrrrrrr}
\hline Dependent & Intercept & MKT & SMB & HML & WML & SRI & Adj. $R^{2}$ & F stat & F. sig \\
\hline P & -0.004 & 0.249 & & & & & & & \\
T statistics & -1.900 & 4.945 & & & & & 0.220 & 24.454 & 0.000 \\
p value & 0.061 & 0.000 & & & & & & & \\
P & 0.000 & 0.260 & 0.550 & 0.494 & & & & \\
T statistics & -0.071 & 6.301 & 4.513 & 3.784 & & & 0.481 & 26.636 & 0.000 \\
p value & 0.943 & 0.000 & 0.000 & 0.000 & & & & & \\
P & -0.001 & 0.258 & 0.549 & 0.494 & 0.124 & & \multirow{2}{*}{0.481} & 20.210 & 0.000 \\
T statistics & -0.547 & 6.252 & 4.503 & 3.783 & 0.983 & & & & \\
p value & 0.586 & 0.000 & 0.000 & 0.000 & 0.329 & & & \\
P & -0.001 & 0.262 & 0.513 & 0.505 & 0.113 & -0.127 & & \\
T statistics & -0.461 & 6.307 & 3.994 & 3.847 & 0.892 & -0.910 & 0.480 & 16.298 & 0.000 \\
p value & 0.646 & 0.000 & 0.000 & 0.000 & 0.375 & 0.366 & & & \\
S & -0.005 & 0.238 & & & & & & & \\
T statistics & -1.998 & 3.846 & & & & & 0.142 & 14.792 & 0.000 \\
p value & 0.049 & 0.000 & & & & & & & \\
S & 0.000 & 0.259 & 1.052 & 1.052 & & & 0.623 & 46.635 & 0.000 \\
T statistics & -0.067 & 6.308 & 8.639 & 3.798 & & & & & \\
p value & 0.946 & 0.000 & 0.000 & 0.000 & & & & & \\
S & -0.001 & 0.258 & 1.051 & 0.495 & 0.124 & & 0.622 & 35.212 & 0.000 \\
T statistics & -0.547 & 6.259 & 8.630 & 3.796 & 0.989 & & & & \\
p value & 0.586 & 0.000 & 0.000 & 0.000 & 0.325 & & & & \\
\hline
\end{tabular}

Table A3: Additional factor model (SRI)

\begin{tabular}{|c|c|c|c|c|c|c|c|c|c|}
\hline Dependent & Intercept & MKT & SMB & HML & WML & SRI & $\operatorname{Adj} . R^{2}$ & F stat & F. sig \\
\hline $\mathrm{S}$ & -0.001 & 0.262 & 1.014 & 0.506 & 0.113 & -0.131 & & & \\
\hline $\mathrm{T}$ statistics & -0.459 & 6.319 & 7.907 & 3.864 & 0.897 & -0.934 & 0.622 & 28.298 & 0.000 \\
\hline $\mathrm{p}$ value & 0.648 & 0.000 & 0.000 & 0.000 & 0.373 & 0.353 & & & \\
\hline $\mathrm{B}$ & -0.003 & 0.257 & & & & & & & \\
\hline $\mathrm{T}$ statistics & -1.525 & 5.800 & & & & & 0.282 & 33.645 & 0.000 \\
\hline $\mathrm{p}$ value & 0.131 & 0.000 & & & & & & & \\
\hline $\mathrm{B}$ & 0.000 & 0.256 & 0.048 & 0.497 & & & & & \\
\hline $\mathrm{T}$ statistics & -0.056 & 6.245 & 0.392 & 3.827 & & & 0.387 & 18.476 & 0.000 \\
\hline $\mathrm{p}$ value & 0.955 & 0.000 & 0.696 & 0.000 & & & & & \\
\hline $\mathrm{B}$ & -0.001 & 0.254 & 0.047 & 0.497 & 0.125 & & & & \\
\hline $\mathrm{T}$ statistics & -0.544 & 6.197 & 0.383 & 3.826 & 1.004 & & 0.387 & 14.110 & 0.000 \\
\hline $\mathrm{p}$ value & 0.588 & 0.000 & 0.703 & 0.000 & 0.319 & & & & \\
\hline $\mathrm{B}$ & -0.001 & 0.258 & 0.012 & 0.508 & 0.115 & -0.123 & & & \\
\hline $\mathrm{T}$ statistics & -0.460 & 6.248 & 0.090 & 3.887 & 0.915 & -0.882 & 0.385 & 11.412 & 0.000 \\
\hline $\mathrm{p}$ value & 0.647 & 0.000 & 0.928 & 0.000 & 0.363 & 0.380 & & & \\
\hline $\mathrm{SH}$ & -0.009 & 0.236 & & & & & & & \\
\hline $\mathrm{T}$ statistics & -2.993 & 3.527 & & & & & 0.121 & 12.439 & 0.001 \\
\hline $\mathrm{p}$ value & 0.004 & 0.001 & & & & & & & \\
\hline $\mathrm{SH}$ & -0.001 & 0.255 & 1.005 & 0.965 & & & & & \\
\hline $\mathrm{T}$ statistics & -0.588 & 6.871 & 9.141 & 8.205 & & & 0.731 & 76.258 & 0.000 \\
\hline $\mathrm{p}$ value & 0.558 & 0.000 & 0.000 & 0.000 & & & & & \\
\hline
\end{tabular}


Empirical investigation of socially responsible investments ...

Table A4: Additional factor model (SRI)

\begin{tabular}{lccccccccc}
\hline Dependent & Intercept & MKT & SMB & HML & WML & SRI & Adj. $R^{2}$ & F stat & F. sig \\
\hline SH & -0.002 & 0.253 & 1.004 & 0.965 & 0.132 & & & & \\
T statistics & -1.090 & 6.831 & 9.152 & 8.223 & 1.170 & & 0.732 & 57.801 & 0.000 \\
p value & 0.279 & 0.000 & 0.000 & 0.000 & 0.245 & & & & \\
SH & -0.002 & 0.257 & 0.975 & 0.974 & 0.124 & -0.101 & & & \\
T statistics & -1.010 & 6.862 & 8.432 & 8.242 & 1.088 & -0.798 & 0.731 & 46.155 & 0.000 \\
p value & 0.316 & 0.000 & 0.000 & 0.000 & 0.280 & 0.427 & & & \\
SL & -0.002 & 0.239 & & & & & & & \\
T statistics & -0.730 & 3.744 & & & & & 0.136 & 14.019 & 0.000 \\
p value & 0.467 & 0.000 & & & & & & & \\
SL & 0.001 & 0.264 & 1.099 & 0.025 & & & 0.494 & 28.055 & 0.000 \\
T statistics & 0.332 & 5.379 & 7.571 & 0.158 & & & & & \\
p value & 0.741 & 0.000 & 0.000 & 0.875 & & & & & \\
SL & 0.000 & 0.262 & 1.098 & 0.024 & 0.116 & & 0.492 & 21.086 & 0.000 \\
T statistics & -0.093 & 5.328 & 7.545 & 0.157 & 0.774 & & & \\
p value & 0.926 & 0.000 & 0.000 & 0.876 & 0.441 & & & & \\
SL & 0.000 & 0.267 & 1.052 & 0.038 & 0.102 & -0.161 & & & \\
T statistics & -0.005 & 5.398 & 6.871 & 0.246 & 0.680 & -0.962 & 0.491 & 17.037 & 0.000 \\
p value & 0.996 & 0.000 & 0.000 & 0.806 & 0.499 & 0.339 & & & \\
SHW & -0.005 & 0.209 & & & & & & & \\
T statistics & -1.533 & 2.786 & & & & & 0.075 & 7.764 & 0.007 \\
p value & 0.129 & 0.007 & & & & & & & \\
\hline
\end{tabular}

Table A5: Additional factor model (SRI)

\begin{tabular}{|c|c|c|c|c|c|c|c|c|c|}
\hline Dependent & Intercept & MKT & SMB & HML & WML & SRI & $\operatorname{Adj} . R^{2}$ & F stat & F. sig \\
\hline SHW & 0.003 & 0.226 & 0.950 & 1.138 & & & & & \\
\hline $\mathrm{T}$ statistics & 1.618 & 4.857 & 6.904 & 7.726 & & & 0.645 & 51.362 & 0.000 \\
\hline $\mathrm{p}$ value & 0.110 & 0.000 & 0.000 & 0.000 & & & & & \\
\hline SHW & -0.001 & 0.218 & 0.946 & 1.138 & 0.529 & & & & \\
\hline $\mathrm{T}$ statistics & -0.474 & 5.131 & 7.514 & 8.445 & 4.081 & & 0.703 & 50.223 & 0.000 \\
\hline $\mathrm{p}$ value & 0.637 & 0.000 & 0.000 & 0.000 & 0.000 & & & & \\
\hline SHW & -0.001 & 0.218 & 0.952 & 1.136 & 0.531 & 0.020 & & & \\
\hline $\mathrm{T}$ statistics & -0.481 & 5.054 & 7.141 & 8.343 & 4.050 & 0.135 & 0.700 & 39.383 & 0.000 \\
\hline $\mathrm{p}$ value & 0.632 & 0.000 & 0.000 & 0.000 & 0.000 & 0.893 & & & \\
\hline SHL & -0.012 & 0.264 & & & & & & & \\
\hline $\mathrm{T}$ statistics & -4.020 & 3.706 & & & & & 0.133 & 13.735 & 0.000 \\
\hline $\mathrm{p}$ value & 0.000 & 0.000 & & & & & & & \\
\hline SHL & -0.005 & 0.284 & 1.059 & 0.792 & & & & & \\
\hline $\mathrm{T}$ statistics & -2.494 & 5.966 & 7.505 & 5.244 & & & 0.613 & 44.767 & 0.000 \\
\hline $\mathrm{p}$ value & 0.015 & 0.015 & 0.000 & 0.000 & & & & & \\
\hline SHL & -0.003 & 0.288 & 1.061 & 0.793 & -0.265 & & & & \\
\hline $\mathrm{T}$ statistics & -1.291 & 6.129 & 7.633 & 5.325 & -1.849 & & 0.624 & 35.444 & 0.000 \\
\hline $\mathrm{p}$ value & 0.201 & 0.000 & 0.000 & 0.000 & 0.068 & & & & \\
\hline SHL & -0.003 & 0.295 & 0.999 & 0.812 & -0.284 & -0.221 & & & \\
\hline $\mathrm{T}$ statistics & -1.166 & 6.281 & 6.866 & 5.463 & -1.982 & -1.393 & 0.628 & 29.081 & 0.000 \\
\hline $\mathrm{p}$ value & 0.247 & 0.000 & 0.000 & 0.000 & 0.051 & 0.168 & & & \\
\hline
\end{tabular}

Business Review: (2018) 13(2):51-80 
Table A6: Additional factor model (SRI)

\begin{tabular}{lccccccccc}
\hline Dependent & Intercept & MKT & SMB & HML & WML & SRI & Adj. $R^{2}$ & F stat & F. sig \\
\hline SHWSRIH & -0.003 & 0.206 & & & & & & & \\
T statistics & -0.881 & 2.771 & & & & & 0.074 & 7.676 & 0.007 \\
p value & 0.381 & 0.007 & & & & & & & \\
SHWSRIH & 0.005 & 0.219 & 0.766 & 0.766 & & & & & \\
T statistics & 2.129 & 4.219 & 4.975 & 6.868 & & & 0.551 & 34.943 & 0.000 \\
p value & 0.036 & 0.000 & 0.000 & 0.000 & & & & & \\
SHWSRIH & 0.002 & 0.214 & 0.763 & 1.131 & 0.385 & & & & \\
T statistics & 0.676 & 4.245 & 5.115 & 7.088 & 2.506 & & 0.579 & 29.508 & 0.000 \\
p value & 0.501 & 0.000 & 0.000 & 0.000 & 0.014 & & & & \\
SHWSRIH & 0.001 & 0.200 & 0.881 & 1.095 & 0.420 & 0.417 & & & \\
T statistics & 0.466 & 4.084 & 5.805 & 7.056 & 2.814 & 2.516 & 0.605 & 26.467 & 0.000 \\
p value & 0.642 & 0.000 & 0.000 & 0.000 & 0.006 & 0.014 & & & \\
SHWSRIL & -0.007 & 0.211 & & & & & & & \\
T statistics & -1.832 & 2.357 & & & & & 0.052 & 5.558 & 0.021 \\
p value & 0.071 & 0.021 & & & & & & & \\
SHWSRIL & 0.002 & 0.232 & 1.135 & 1.145 & & & & \\
T statistics & 0.634 & 3.705 & 6.113 & 5.764 & & & 0.538 & 33.155 & 0.000 \\
p value & 0.528 & 0.000 & 0.000 & 0.000 & & & & & \\
SHWSRIL & -0.004 & 0.223 & 1.129 & 1.145 & 0.674 & & & & \\
T statistics & -1.282 & 3.838 & 6.576 & 6.228 & 3.808 & & 0.604 & 32.687 & 0.000 \\
p value & 0.204 & 0.000 & 0.000 & 0.000 & 0.000 & & & & \\
\hline
\end{tabular}

Table A7: Additional factor model (SRI)

\begin{tabular}{|c|c|c|c|c|c|c|c|c|c|}
\hline Dependent & Intercept & MKT & SMB & HML & WML & SRI & $\operatorname{Adj} . R^{2}$ & F stat & F. sig \\
\hline SHWSRIL & -0.003 & 0.235 & 1.022 & 1.178 & 0.642 & -0.378 & & & \\
\hline $\mathrm{T}$ statistics & -1.121 & 4.095 & 5.757 & 6.492 & 3.675 & -1.949 & 0.618 & 27.836 & 0.000 \\
\hline $\mathrm{p}$ value & 0.266 & 0.000 & 0.000 & 0.000 & 0.000 & 0.055 & & & \\
\hline SHLSRIH & -0.010 & 0.275 & & & & & & & \\
\hline $\mathrm{T}$ statistics & -2.879 & 3.385 & & & & & 0.112 & 11.460 & 0.001 \\
\hline $\mathrm{p}$ value & 0.005 & 0.001 & & & & & & & \\
\hline SHLSRIH & -0.002 & 0.293 & 0.926 & 0.996 & & & & & \\
\hline $\mathrm{T}$ statistics & -0.879 & 4.775 & 5.105 & 5.132 & & & 0.499 & 28.570 & 0.000 \\
\hline $\mathrm{p}$ value & 0.382 & 0.000 & 0.000 & 0.000 & & & & & \\
\hline SHLSRIH & 0.001 & 0.298 & 0.929 & 0.997 & -0.413 & & & & \\
\hline $\mathrm{T}$ statistics & 0.335 & 4.990 & 5.255 & 5.265 & -2.268 & & 0.524 & 23.822 & 0.000 \\
\hline $\mathrm{p}$ value & 0.739 & 0.000 & 0.000 & 0.000 & 0.026 & & & & \\
\hline SHLSRIH & 0.001 & 0.288 & 1.019 & 0.969 & -0.386 & 0.317 & & & \\
\hline $\mathrm{T}$ statistics & 0.192 & 4.834 & 5.531 & 5.143 & -2.131 & 1.576 & 0.533 & 19.913 & 0.000 \\
\hline $\mathrm{p}$ value & 0.848 & 0.000 & 0.000 & 0.000 & 0.036 & 0.119 & & & \\
\hline SHLSRIL & -0.015 & 0.252 & & & & & & & \\
\hline $\mathrm{T}$ statistics & -3.915 & 2.920 & & & & & 0.083 & 8.527 & 0.005 \\
\hline $\mathrm{p}$ value & 0.000 & 0.005 & & & & & & & \\
\hline SHLSRIL & -0.008 & 0.276 & 1.193 & 0.588 & & & & & \\
\hline $\mathrm{T}$ statistics & -2.678 & 4.022 & 5.863 & 2.703 & & & 0.421 & 21.155 & 0.000 \\
\hline $\mathrm{p}$ value & 0.009 & 0.000 & 0.000 & 0.008 & & & & & \\
\hline
\end{tabular}


Empirical investigation of socially responsible investments ...

Table A8: Additional factor model (SRI)

\begin{tabular}{lccccccccc}
\hline Dependent & Intercept & MKT & SMB & HML & WML & SRI & Adj. $R^{2}$ & F stat & F. sig \\
\hline SHLSRIL & -0.007 & 0.278 & 1.194 & 0.589 & -0.117 & & & & \\
T statistics & -2.046 & 4.025 & 5.842 & 2.691 & -0.554 & & 0.416 & 15.805 & 0.000 \\
p value & 0.044 & 0.000 & 0.000 & 0.009 & 0.581 & & & & \\
SHLSRIL & -0.006 & 0.303 & 0.978 & 0.655 & -0.181 & -0.759 & & & \\
T statistics & -1.859 & 4.646 & 4.854 & 3.182 & -0.912 & -3.454 & 0.487 & 16.779 & 0.000 \\
p value & 0.067 & 0.000 & 0.000 & 0.002 & 0.365 & 0.001 & & & \\
SLW & 0.001 & 0.240 & & & & & & & \\
T statistics & 0.834 & 0.001 & & & & & 0.107 & 10.930 & 0.001 \\
p value & 0.210 & 3.306 & & & & & & & \\
SLW & 0.003 & 0.266 & 1.151 & -0.006 & & & 0.415 & 20.640 & 0.000 \\
T statistics & 1.241 & 4.509 & 6.597 & -0.031 & & & & & \\
p value & 0.218 & 0.000 & 0.000 & 0.976 & & & & & \\
SLW & -0.003 & 0.255 & 1.144 & -0.007 & 0.755 & & 0.538 & 25.206 & 0.000 \\
T statistics & -1.117 & 4.869 & 7.386 & -0.039 & 4.729 & & & \\
p value & 0.267 & 0.000 & 0.000 & 0.969 & 0.000 & & & & \\
SLW & -0.003 & 0.261 & 1.092 & 0.010 & 0.740 & -0.184 & & \\
T statistics & -1.018 & 4.955 & 6.703 & 0.058 & 4.614 & -1.035 & 0.539 & 20.397 & 0.000 \\
p value & 0.312 & 0.000 & 0.000 & 0.954 & 0.000 & 0.304 & & & \\
SLL & -0.005 & 0.239 & & & & & & & \\
T statistics & -1.441 & 3.166 & & & & & 0.098 & 10.026 & 0.002 \\
p value & 0.153 & 0.002 & & & & & & & \\
\hline
\end{tabular}

Table A9: Additional factor model (SRI)

\begin{tabular}{|c|c|c|c|c|c|c|c|c|c|}
\hline Dependent & Intercept & $\mathrm{MKT}$ & SMB & HML & WML & SRI & $\operatorname{Adj} . R^{2}$ & F stat & F. sig \\
\hline SLL & -0.002 & 0.262 & 1.047 & 0.055 & & & & & \\
\hline $\mathrm{T}$ statistics & -0.626 & 4.043 & 5.463 & 0.267 & & & 0.338 & 15.135 & 0.000 \\
\hline $\mathrm{p}$ value & 0.533 & 0.000 & 0.000 & 0.790 & & & & & \\
\hline SLL & 0.003 & 0.269 & 1.052 & 0.055 & -0.523 & & & & \\
\hline $\mathrm{T}$ statistics & 0.791 & 4.320 & 5.706 & 0.281 & -2.754 & & 0.388 & 14.182 & 0.000 \\
\hline $\mathrm{p}$ value & 0.431 & 0.000 & 0.000 & 0.780 & 0.007 & & & & \\
\hline SLL & 0.003 & 0.274 & 1.013 & 0.067 & -0.535 & -0.137 & & & \\
\hline $\mathrm{T}$ statistics & 0.844 & 4.349 & 5.203 & 0.339 & -2.792 & -0.647 & 0.384 & 11.346 & 0.000 \\
\hline $\mathrm{p}$ value & 0.401 & 0.000 & 0.000 & 0.736 & 0.007 & 0.519 & & & \\
\hline SLWSRIH & -0.001 & 0.200 & & & & & & & \\
\hline $\mathrm{T}$ statistics & -0.370 & 2.879 & & & & & 0.081 & 8.289 & 0.005 \\
\hline $\mathrm{p}$ value & 0.712 & 0.005 & & & & & & & \\
\hline SLWSRIH & 0.001 & 0.217 & 0.780 & -0.005 & & & & & \\
\hline $\mathrm{T}$ statistics & 0.249 & 3.407 & 4.132 & -0.024 & & & 0.229 & 9.203 & 0.000 \\
\hline $\mathrm{p}$ value & 0.804 & 0.001 & 0.000 & 0.981 & & & & & \\
\hline SLWSRIH & -0.004 & 0.209 & 0.775 & -0.006 & 0.603 & & & & \\
\hline $\mathrm{T}$ statistics & -1.390 & 3.466 & 4.349 & -0.029 & 3.284 & & 0.313 & 10.443 & 0.000 \\
\hline $\mathrm{p}$ value & 0.169 & 0.001 & 0.000 & 0.977 & 0.002 & & & & \\
\hline SLWSRIH & -0.005 & 0.192 & 0.925 & -0.052 & 0.648 & 0.527 & & & \\
\hline $\mathrm{T}$ statistics & -1.681 & 3.284 & 5.122 & -0.280 & 3.645 & 2.672 & 0.362 & 10.432 & 0.000 \\
\hline $\mathrm{p}$ value & 0.097 & 0.002 & 0.000 & 0.780 & 0.000 & 0.009 & & & \\
\hline
\end{tabular}

Business Review: (2018) 13(2):51-80 
Table A10: Additional factor model (SRI)

\begin{tabular}{lccccccccc}
\hline Dependent & Intercept & MKT & SMB & HML & WML & SRI & Adj. $R^{2}$ & F stat & F. sig \\
\hline SLWSRIL & 0.002 & 0.280 & & & & & & & \\
T statistics & 0.547 & 2.723 & & & & & 0.072 & 7.415 & 0.008 \\
p value & 0.586 & 0.008 & & & & & & & \\
SLWSRIL & 0.006 & 0.314 & 1.521 & -0.007 & & & & & \\
T statistics & 1.507 & 3.631 & 5.941 & -0.024 & & & 0.348 & 15.748 & 0.000 \\
p value & 0.136 & 0.000 & 0.000 & 0.981 & & & & & \\
SLWSRIL & -0.002 & 0.301 & 1.514 & -0.008 & 0.907 & & & & \\
T statistics & -0.414 & 3.747 & 6.364 & -0.030 & 3.701 & & 0.437 & 17.110 & 0.000 \\
p value & 0.680 & 0.000 & 0.000 & 0.977 & 0.000 & & & & \\
SLWSRIL & 0.000 & 0.330 & 1.259 & 0.071 & 0.831 & -0.894 & & & \\
T statistics & -0.121 & 4.364 & 5.380 & 0.296 & 3.610 & -3.503 & 0.507 & 18.094 & 0.000 \\
p value & 0.904 & 0.000 & 0.000 & 0.768 & 0.001 & 0.001 & & & \\
SLLSRIH & -0.004 & 0.266 & & & & & & & \\
T statistics & -1.092 & 3.115 & & & & & 0.095 & 9.704 & 0.003 \\
p value & 0.278 & 0.003 & & & & & & & \\
SLLSRIH & -0.002 & 0.286 & 0.905 & 0.025 & & & 0.224 & 8.992 & 0.000 \\
T statistics & -0.466 & 3.609 & 3.857 & 0.101 & & & & & \\
p value & 0.642 & 0.001 & 0.000 & 0.920 & & & & & \\
SLLSRIH & 0.002 & 0.292 & 0.908 & 0.026 & -0.438 & & \multirow{2}{*}{0.247} & 7.789 & 0.000 \\
T statistics & 0.495 & 3.737 & 3.929 & 0.104 & -1.838 & & & & \\
p value & 0.622 & 0.000 & 0.000 & 0.917 & 0.070 & & & \\
\hline
\end{tabular}

Table A11: Additional factor model (SRI)

\begin{tabular}{lccccccccc}
\hline Dependent & Intercept & MKT & SMB & HML & WML & SRI & Adj. $R^{2}$ & F stat & F. sig \\
\hline SLLSRIH & 0.007 & 0.262 & 1.172 & -0.056 & -0.359 & 0.928 & & & \\
T statistics & 0.187 & 3.602 & 5.212 & -0.242 & -1.623 & 3.784 & 0.355 & 10.145 & 0.000 \\
p value & 0.852 & 0.001 & 0.000 & 0.810 & 0.109 & 0.000 & & & \\
SLLSRIL & -0.005 & 0.212 & & & & & & & \\
T statistics & -1.201 & 2.046 & & & & & 0.037 & 4.186 & 0.044 \\
p value & 0.200 & 0.044 & & & & & & \\
SLLSRIL & -0.002 & 0.238 & 1.190 & 0.084 & & & & \\
T statistics & -0.469 & 2.526 & 4.271 & 0.282 & & & 0.207 & 8.218 & 0.000 \\
p value & 0.640 & 0.013 & 0.000 & 0.778 & & & & \\
SLLSRIL & 0.003 & 0.246 & 1.195 & 0.085 & -0.608 & & & \\
T statistics & 0.651 & 2.674 & 4.386 & 0.291 & -2.166 & & 0.242 & 7.621 & 0.000 \\
p value & 0.517 & 0.009 & 0.000 & 0.772 & 0.033 & & & & \\
SLLSRIL & 0.005 & 0.285 & 0.853 & 0.190 & -0.710 & -1.203 & & & \\
T statistics & 1.102 & 3.394 & 3.280 & 0.716 & -2.775 & -4.241 & 0.376 & 11.006 & 0.000 \\
p value & 0.274 & 0.001 & 0.002 & 0.476 & 0.007 & 0.000 & & & \\
BH & -0.005 & 0.261 & & & & & & \\
T statistics & -1.872 & 4.286 & & & & & 0.173 & 18.368 & 0.000 \\
p value & 0.065 & 0.000 & & & & & &
\end{tabular}


Empirical investigation of socially responsible investments ...

Table A12: Additional factor model (SRI)

\begin{tabular}{lccccccccc}
\hline Dependent & Intercept & MKT & SMB & HML & WML & SRI & Adj. $R^{2}$ & F stat & F. sig \\
\hline BH & 0.000 & 0.258 & 0.092 & 1.027 & 0.119 & & & & \\
T statistics & -0.061 & 5.260 & 0.633 & 6.620 & 0.795 & & 0.468 & 19.248 & 0.000 \\
p value & 0.951 & 0.000 & 0.528 & 0.000 & 0.429 & & & & \\
BH & 0.000 & 0.263 & 0.049 & 1.040 & 0.106 & -0.151 & & & \\
T statistics & 0.022 & 5.322 & 0.320 & 6.668 & 0.706 & -0.908 & 0.467 & 15.528 & 0.000 \\
p value & 0.982 & 0.000 & 0.750 & 0.000 & 0.483 & 0.367 & & & \\
BL & -0.001 & 0.255 & & & & & & \\
T statistics & -0.512 & 6.956 & & & & & & \\
p value & 0.610 & 0.000 & & & & & & \\
BL & -0.001 & 0.255 & -0.003 & -0.038 & & & & \\
T statistics & -0.594 & 6.861 & -0.026 & -0.326 & & & & \\
p value & 0.554 & 0.000 & 0.979 & 0.745 & & & & \\
BL & -0.002 & 0.253 & -0.004 & -0.039 & 0.130 & & & \\
T statistics & -1.086 & 6.820 & -0.036 & -0.328 & 1.152 & & 0.351 & 12.228 & 0.0000 \\
p value & 0.281 & 0.000 & 0.971 & 0.744 & 0.253 & & & \\
BL & -0.002 & 0.256 & -0.029 & -0.031 & 0.123 & -0.086 & & \\
T statistics & -1.016 & 6.831 & -0.246 & -0.262 & 1.079 & -0.684 & 0.347 & 9.810 & 0.000 \\
p value & 0.313 & 0.000 & 0.806 & 0.794 & 0.284 & 0.496 & & &
\end{tabular}

Table A13: Additional factor model (SRI)

\begin{tabular}{|c|c|c|c|c|c|c|c|c|c|}
\hline Dependent & Intercept & MKT & SMB & HML & WML & SRI & $\operatorname{Adj} . R^{2}$ & F stat & F. sig \\
\hline BHW & 0.005 & 0.286 & 0.191 & 1.015 & & & & & \\
\hline $\mathrm{T}$ statistics & 1.755 & 4.528 & 1.025 & 5.081 & & & 0.365 & 16.875 & 0.000 \\
\hline $\mathrm{p}$ value & 0.083 & 0.000 & 0.309 & 0.000 & & & & & \\
\hline $\mathrm{BHW}$ & 0.000 & 0.277 & 0.186 & 1.015 & 0.640 & & & & \\
\hline $\mathrm{T}$ statistics & -0.123 & 4.691 & 1.067 & 5.436 & 3.564 & & 0.446 & 17.683 & 0.000 \\
\hline $\mathrm{p}$ value & 0.903 & 0.000 & 0.289 & 0.000 & 0.001 & & & & \\
\hline $\mathrm{BHW}$ & 0.000 & 0.279 & 0.162 & 0.022 & 0.633 & -0.085 & & & \\
\hline $\mathrm{T}$ statistics & -0.083 & 4.685 & 0.877 & 5.424 & 3.490 & -0.425 & 0.440 & 14.036 & 0.000 \\
\hline $\mathrm{p}$ value & 0.934 & 0.000 & 0.383 & 0.000 & 0.001 & 0.672 & & & \\
\hline BHL & -0.009 & 0.247 & & & & & & & \\
\hline $\mathrm{T}$ statistics & -3.404 & 3.911 & & & & & 0.147 & 15.292 & 0.000 \\
\hline $\mathrm{p}$ value & 0.001 & 0.000 & & & & & & & \\
\hline $\mathrm{BHL}$ & -0.004 & 0.240 & 0.009 & 1.033 & & & & & \\
\hline $\mathrm{T}$ statistics & -1.515 & 4.672 & 0.057 & 6.258 & & & 0.422 & 21.158 & 0.000 \\
\hline $\mathrm{p}$ value & 0.134 & 0.000 & 0.955 & 0.000 & & & & & \\
\hline $\mathrm{BHL}$ & 0.000 & 0.249 & 0.012 & 1.033 & -0.409 & & & & \\
\hline $\mathrm{T}$ statistics & -0.050 & 4.958 & 0.081 & 6.496 & -2.672 & & 0.463 & 18.873 & 0.000 \\
\hline $\mathrm{p}$ value & 0.961 & 0.000 & 0.935 & 0.000 & 0.009 & & & & \\
\hline $\mathrm{BHL}$ & 0.000 & 0.257 & -0.056 & 1.054 & -0.429 & -0.239 & & & \\
\hline $\mathrm{T}$ statistics & 0.079 & 5.113 & -0.360 & 6.640 & -2.810 & -1.410 & 0.469 & 15.685 & 0.000 \\
\hline $\mathrm{p}$ value & 0.937 & 0.000 & 0.720 & 0.000 & 0.006 & 0.162 & & & \\
\hline
\end{tabular}

Business Review: (2018) 13(2):51-80 
Table A14: Additional factor model (SRI)

\begin{tabular}{lccccccccc}
\hline Dependent & Intercept & MKT & SMB & HML & WML & SRI & Adj. $R^{2}$ & F stat & F. sig \\
\hline BHWSRIH & -0.001 & 0.332 & & & & & & & \\
T statistics & -0.240 & 4.296 & & & & & 0.174 & 18.452 & 0.000 \\
p value & 0.811 & 0.000 & & & & & & & \\
BHWSRIH & 0.005 & 0.329 & 0.011 & 1.068 & & & & & \\
T statistics & 1.580 & 4.808 & 0.056 & 4.930 & & & 0.357 & 16.382 & 0.000 \\
p value & 0.118 & 0.000 & 0.956 & 0.000 & & & & & \\
BHWSRIH & 0.000 & 0.321 & 0.007 & 1.068 & 0.560 & & & & \\
T statistics & 0.052 & 4.885 & 0.035 & 5.133 & 2.797 & & 0.408 & 15.291 & 0.000 \\
p value & 0.959 & 0.000 & 0.972 & 0.000 & 0.006 & & & & \\
BHWSRIH & 0.000 & 0.322 & -0.005 & 1.071 & 0.557 & -0.041 & & & \\
T statistics & 0.068 & 4.846 & -0.024 & 5.097 & 2.751 & -0.184 & 0.401 & 12.090 & 0.000 \\
p value & 0.946 & 0.000 & 0.981 & 0.000 & 0.001 & 0.854 & & & \\
BHWSRIL & -0.001 & 0.238 & & & & & & & \\
T statistics & -0.242 & 2.940 & & & & & 0.084 & 8.643 & 0.004 \\
p value & 0.809 & 0.004 & & & & & & & \\
BHWSRIL & 0.005 & 0.242 & 0.371 & 0.963 & & & 0.285 & 12.035 & 0.000 \\
T statistics & 1.585 & 3.387 & 1.753 & 4.245 & & & & & \\
p value & 0.117 & 0.001 & 0.083 & 0.000 & & & & & \\
BHWSRIL & -0.001 & 0.232 & 0.365 & 0.962 & 0.721 & & \multirow{2}{*}{0.375} & 13.434 & 0.000 \\
T statistics & -0.267 & 3.468 & 1.844 & 4.535 & 3.530 & & & & \\
p value & 0.790 & 0.001 & 0.069 & 0.000 & 0.001 & & & & \\
\hline
\end{tabular}

Table A15: Additional factor model (SRI)

\begin{tabular}{lccccccccc}
\hline Dependent & Intercept & MKT & SMB & HML & WML & SRI & Adj. $R^{2}$ & F stat & F. sig \\
\hline BHWSRIL & -0.001 & 0.237 & 0.329 & 0.973 & 0.710 & -0.130 & & & \\
T statistics & -0.213 & 3.494 & 1.570 & 4.549 & 3.446 & -0.568 & 0.369 & 10.719 & 0.000 \\
p value & 0.832 & 0.001 & 0.121 & 0.000 & 0.001 & 0.572 & & & \\
BHLSRIH & -0.009 & 0.296 & & & & & & & \\
T statistics & -3.299 & 4.425 & & & & & 0.000 & 19.583 & 0.000 \\
p value & 0.001 & 0.000 & & & & & & \\
BHLSRIH & -0.005 & 0.291 & -0.075 & 0.939 & & & & \\
T statistics & -1.686 & 4.921 & -0.430 & 5.006 & & & 0.364 & 16.852 & 0.000 \\
p value & 0.096 & 0.000 & 0.669 & 0.000 & & & & \\
BHLSRIH & -0.002 & 0.296 & -0.073 & 0.940 & -0.307 & & & \\
T statistics & -0.636 & 5.050 & -0.421 & 5.068 & -1.720 & & 0.379 & 13.689 & 0.000 \\
p value & 0.526 & 0.000 & 0.675 & 0.000 & 0.089 & & & & \\
BHLSRIH & -0.002 & 0.293 & -0.053 & 0.933 & -0.301 & 0.070 & & & \\
T statistics & -0.662 & 4.954 & -0.288 & 4.985 & -1.670 & 0.353 & 0.373 & 10.854 & 0.000 \\
p value & 0.510 & 0.000 & 0.774 & 0.000 & 0.099 & 0.725 & & & \\
BHLSRIL & -0.009 & 0.197 & & & & & & \\
T statistics & -2.861 & 2.702 & & & & & 0.071 & 7.303 & 0.008 \\
p value & 0.005 & 0.008 & & & & & & &
\end{tabular}


Empirical investigation of socially responsible investments ...

Table A16: Additional factor model (SRI)

\begin{tabular}{|c|c|c|c|c|c|c|c|c|c|}
\hline Dependent & Intercept & MKT & SMB & HML & WML & SRI & $\operatorname{Adj} . R^{2}$ & F stat & F. sig \\
\hline BHLSRIL & 0.002 & 0.202 & 0.097 & 1.127 & -0.511 & & & & \\
\hline $\mathrm{T}$ statistics & 0.549 & 3.440 & 0.557 & 6.049 & -2.851 & & 0.399 & 14.777 & 0.000 \\
\hline $\mathrm{p}$ value & 0.585 & 0.001 & 0.579 & 0.000 & 0.006 & & & & \\
\hline BHLSRIL & 0.002 & 0.220 & -0.059 & 1.175 & -0.558 & -0.548 & & & \\
\hline $\mathrm{T}$ statistics & 0.833 & 3.886 & -0.337 & 6.560 & -3.234 & -2.868 & 0.449 & 14.549 & 0.000 \\
\hline $\mathrm{p}$ value & 0.408 & 0.000 & 0.737 & 0.000 & 0.002 & 0.005 & & & \\
\hline BLW & 0.006 & 0.290 & & & & & & & \\
\hline $\mathrm{T}$ statistics & 2.558 & 5.580 & & & & & 0.266 & 31.135 & 0.000 \\
\hline $\mathrm{p}$ value & 0.012 & 0.000 & & & & & & & \\
\hline BLW & 0.005 & 0.290 & -0.066 & -0.166 & & & & & \\
\hline $\mathrm{T}$ statistics & 1.932 & 5.530 & -0.426 & -1.001 & & & 0.261 & 10.772 & 0.000 \\
\hline p value & 0.057 & 0.000 & 0.671 & 0.320 & & & & & \\
\hline BLW & 0.000 & 0.282 & -0.071 & -0.167 & 0.572 & & & & \\
\hline $\mathrm{T}$ statistics & -0.091 & 5.824 & -0.494 & -1.089 & 3.880 & & 0.371 & 13.262 & 0.000 \\
\hline $\mathrm{p}$ value & 0.927 & 0.000 & 0.623 & 0.280 & 0.000 & & & & \\
\hline BLW & 0.000 & 0.291 & -0.149 & -0.142 & 0.548 & -0.277 & & & \\
\hline $\mathrm{T}$ statistics & 0.064 & 6.046 & -1.005 & -0.937 & 3.749 & -1.708 & 0.386 & 11.450 & 0.000 \\
\hline $\mathrm{p}$ value & 0.949 & 0.000 & 0.318 & 0.352 & 0.000 & 0.092 & & & \\
\hline BLL & -0.007 & 0.219 & & & & & & & \\
\hline $\mathrm{T}$ statistics & -4.179 & 5.359 & & & & & 0.250 & 28.714 & 0.000 \\
\hline $\mathrm{p}$ value & 0.000 & 0.000 & & & & & & & \\
\hline
\end{tabular}

Table A17: Additional factor model (SRI)

\begin{tabular}{|c|c|c|c|c|c|c|c|c|c|}
\hline Dependent & Intercept & MKT & SMB & HML & WML & SRI & $\operatorname{Adj} . R^{2}$ & F stat & F. sig \\
\hline BLL & -0.007 & 0.220 & 0.060 & 0.089 & & & & & \\
\hline $\mathrm{T}$ statistics & -3.526 & 5.334 & 0.494 & 0.684 & & & 0.240 & 9.734 & 0.000 \\
\hline $\mathrm{p}$ value & 0.001 & 0.623 & 0.623 & 0.496 & & & & & \\
\hline BLL & -0.004 & 0.224 & 0.063 & 0.090 & -0.311 & & & & \\
\hline $\mathrm{T}$ statistics & -1.909 & 5.621 & 0.532 & 0.709 & -2.561 & & 0.289 & 9.447 & 0.000 \\
\hline $\mathrm{p}$ value & 0.060 & 0.000 & 0.596 & 0.480 & 0.012 & & & & \\
\hline BLL & -0.004 & 0.221 & 0.092 & 0.080 & -0.302 & 0.104 & & & \\
\hline $\mathrm{T}$ statistics & -1.966 & 5.489 & 0.743 & 0.633 & -2.471 & 0.768 & 0.286 & 7.636 & 0.000 \\
\hline $\mathrm{p}$ value & 0.053 & 0.000 & 0.451 & 0.529 & 0.016 & 0.445 & & & \\
\hline BLWSRIH & 0.007 & 0.376 & & & & & & & \\
\hline $\mathrm{T}$ statistics & 2.151 & 5.104 & & & & & 0.232 & 26.046 & 0.000 \\
\hline $\mathrm{p}$ value & 0.034 & 0.000 & & & & & & & \\
\hline BLWSRIH & 0.006 & 0.373 & -0.119 & -0.012 & & & & & \\
\hline $\mathrm{T}$ statistics & 1.876 & 5.004 & -0.537 & -0.050 & & & 0.216 & 8.608 & 0.000 \\
\hline $\mathrm{p}$ value & 0.064 & 0.000 & 0.593 & 0.960 & & & & & \\
\hline BLWSRIH & 0.000 & 0.363 & -0.125 & -0.013 & 0.737 & & & & \\
\hline $\mathrm{T}$ statistics & 0.037 & 5.182 & -0.602 & -0.057 & 3.452 & & 0.310 & 10.317 & 0.000 \\
\hline $\mathrm{p}$ value & 0.971 & 0.000 & 0.549 & 0.955 & 0.001 & & & & \\
\hline BLWSRIH & 0.000 & 0.355 & -0.051 & -0.035 & 0.759 & 0.259 & & & \\
\hline $\mathrm{T}$ statistics & -0.063 & 5.038 & -0.234 & -0.158 & 3.543 & 1.090 & 0.312 & 8.511 & 0.000 \\
\hline $\mathrm{p}$ value & 0.950 & 0.000 & 0.815 & 0.875 & 0.001 & 0.279 & & & \\
\hline
\end{tabular}

Business Review: (2018) 13(2):51-80 
Table A18: Additional factor model (SRI)

\begin{tabular}{|c|c|c|c|c|c|c|c|c|c|}
\hline Dependent & Intercept & MKT & SMB & HML & WML & SRI & $\operatorname{Adj} . R^{2}$ & F stat & F. sig \\
\hline BLWSRIL & 0.005 & 0.205 & & & & & & & \\
\hline $\mathrm{T}$ Statistics & 1.742 & 3.309 & & & & & 0.107 & 10.950 & 0.001 \\
\hline $\mathrm{p}$ value & 0.085 & 0.001 & & & & & & & \\
\hline BLWSRIL & 0.003 & 0.206 & -0.013 & -0.320 & & & & & \\
\hline $\mathrm{T}$ statistics & 1.010 & 3.331 & -0.073 & -1.636 & & & 0.116 & 4.634 & 0.005 \\
\hline $\mathrm{p}$ value & 0.316 & 0.001 & 0.942 & 0.106 & & & & & \\
\hline BLWSRIL & -0.001 & 0.200 & -0.017 & -0.321 & 0.406 & & & & \\
\hline $\mathrm{T}$ statistics & -0.189 & 3.314 & -0.093 & -1.677 & 2.207 & & 0.157 & 4.862 & 0.001 \\
\hline $\mathrm{p}$ value & 0.850 & 0.001 & 0.926 & 0.097 & 0.030 & & & & \\
\hline BLWSRIL & 0.001 & 0.226 & -0.248 & -0.249 & 0.338 & -0.813 & & & \\
\hline $\mathrm{T}$ statistics & 0.193 & 4.138 & -1.464 & -1.442 & 2.027 & -4.401 & 0.316 & 8.668 & 0.000 \\
\hline $\mathrm{p}$ value & 0.848 & 0.000 & 0.147 & 0.153 & 0.046 & 0.000 & & & \\
\hline BLLSRIH & -0.008 & 0.192 & & & & & & & \\
\hline $\mathrm{T}$ statistics & -2.851 & 2.999 & & & & & 0.088 & 8.994 & 0.004 \\
\hline $\mathrm{p}$ value & 0.006 & 0.004 & & & & & & & \\
\hline BLLSRIH & -0.007 & 0.194 & 0.095 & 0.171 & & & & & \\
\hline $\mathrm{T}$ statistics & -2.250 & 3.000 & 0.495 & 0.834 & & & 0.078 & 3.350 & 0.023 \\
\hline $\mathrm{p}$ value & 0.027 & 0.004 & 0.622 & 0.407 & & & & & \\
\hline BLLSRIH & -0.003 & 0.200 & 0.099 & 0.171 & -0.470 & & & & \\
\hline $\mathrm{T}$ statistics & -0.805 & 3.195 & 0.531 & 0.862 & -2.458 & & 0.133 & 4.182 & 0.004 \\
\hline $\mathrm{p}$ value & 0.423 & 0.002 & 0.597 & 0.391 & 0.016 & & & & \\
\hline
\end{tabular}

Table A19: Additional factor model (SRI)

\begin{tabular}{lccccccccc}
\hline Dependent & Intercept & MKT & SMB & HML & WML & SRI & Adj.R & F stat & F. sig \\
\hline BLLSRIH & -0.003 & 0.186 & 0.227 & 0.132 & -0.432 & 0.453 & & & \\
T statistics & -1.020 & 3.012 & 1.192 & 0.675 & -2.301 & 2.178 & 0.172 & 4.452 & 0.001 \\
p value & 0.311 & 0.003 & 0.237 & 0.502 & 0.024 & 0.032 & & & \\
BLLSRIL & -0.007 & 0.247 & & & & & & & \\
T statistics & -3.670 & 5.569 & & & & & 0.266 & 31.019 & 0.000 \\
p value & 0.000 & 0.000 & & & & & & \\
BLLSRIL & -0.007 & 0.249 & 0.080 & 0.034 & & & & \\
T statistics & -3.196 & 5.542 & 0.602 & 0.240 & & & 0.252 & 10.316 & 0.000 \\
p value & 0.002 & 0.000 & 0.549 & 0.811 & & & & \\
BLLSRIL & -0.005 & 0.251 & 0.081 & 0.034 & -0.138 & & & \\
T statistics & -2.285 & 5.580 & 0.610 & 0.241 & -1.005 & & 0.252 & 7.990 & 0.000 \\
p value & 0.025 & 0.000 & 0.543 & 0.811 & 0.318 & & & \\
BLLSRIL & -0.005 & 0.262 & -0.017 & 0.064 & -0.167 & -0.345 & & \\
T statistics & -2.125 & 5.953 & -0.125 & 0.464 & -1.246 & -2.324 & 0.291 & 7.829 & 0.000 \\
p value & 0.037 & 0.000 & 0.901 & 0.644 & 0.216 & 0.023 & & & \\
\hline
\end{tabular}

